
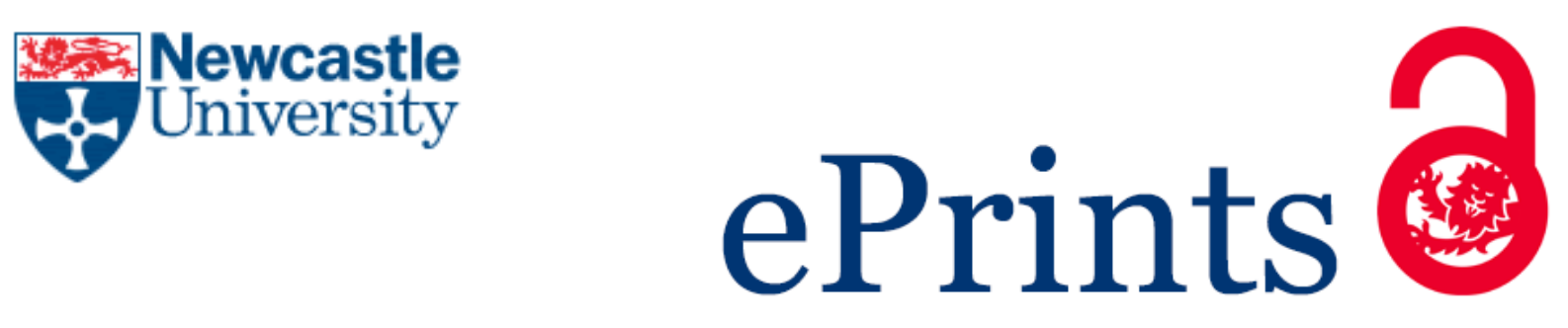

Bigley V, Cytlak U, Collin M. Human dendritic cell immunodeficiencies.

Seminars in Cell \& Developmental Biology 2018. DOI:

10.1016/j.semcdb.2018.02.020

\title{
Copyright:
}

(C) 2018. This manuscript version is made available under the CC-BY-NC-ND 4.0 license

DOI link to article:

https://doi.org/10.1016/i.semcdb.2018.02.020

Date deposited:

$27 / 02 / 2018$

Embargo release date:

23 February 2019

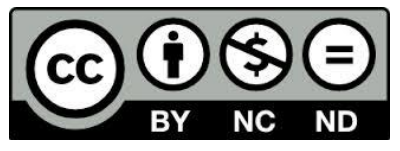

This work is licensed under a

Creative Commons Attribution-NonCommercial-NoDerivatives 4.0 International licence 


\title{
Seminars in Cell and Developmental Biology
}

\section{Human Dendritic Cell Immunodeficiencies}

Venetia Bigley ${ }^{1,2}$, Urszula Cytlak ${ }^{1}$, Matthew Collin ${ }^{1,2}$

1. Human DC Lab, Institute of Cellular Medicine, Newcastle University, Newcastle upon Tyne, UK.

2. Newcastle Hospitals NHS Foundation Trust, Newcastle upon Tyne, UK.

\section{Corresponding author:}

Venetia Bigley: venetia.bigley@ncl.ac.uk

\section{Conflicts of interest:}

None

\begin{abstract}
The critical functions of dendritic cells (DCs) in immunity and tolerance have been demonstrated in many animal models but their non-redundant roles in humans are more difficult to probe. Human primary immunodeficiency (PID), resulting from single gene mutations, may result in DC deficiency or dysfunction. This relatively recent recognition illuminates the in vivo role of human DCs and the pathophysiology of the associated clinical syndromes. In this review, the development and function of DCs as established in murine models and human in vitro systems, is discussed. This forms the basis of predicting the effects of DC deficiency in vivo and understanding the consequences of specific mutations on DC development and function. DC deficiency syndromes are associated with heterozygous GATA2 mutation, bi-allelic and heterozygous IRF8 mutation and heterozygous IKZF1 mutation. The intricate involvement of DCs in the balance between immunity and tolerance is leading to increased recognition of their involvement in a number of other immunodeficiency and autoimmune conditions. Owing to the precise control of transcription factor gene expression by super-enhancer elements, phenotypic anomalies are relatively commonly caused by heterozygous mutations.
\end{abstract}

\section{Key words:}

dendritic cells; primary immunodeficiency; autoimmunity; IRF8; GATA2; IKZF1 


\section{The role of Dendritic cells in Immunity and Tolerance}

\section{Immunity}

As professional antigen presenting cells, the prototypic function of Dendritic Cells (DCs) is to activate and prime naïve helper and cytotoxic $T$ cell responses. $T$ cell receptor (TCR) recognition of cognate antigen in the context of $\mathrm{MHC}$ provides specificity. $T$ cell activation is driven by a second co-stimulatory signal generated through the binding of CD28 on the T cell with B7 molecules (CD80 and CD86) on the DC. Cytokine secretion by DCs provides a third signal, triggering specific STAT activation pathways to determine $T$ effector lineage. The specificity of cytokine secretion is determined by recognition of pathogen-associated molecular patterns (PAMPs) by pattern recognition receptors (PRRs) on DCs, including Toll-like receptors (TLRs), NOD-like receptors (NLRs) and RIG-l-like receptors (RLRs), a process also resulting in DC activation with up regulation of co-stimulatory and $\mathrm{MHC}$ molecules. These processes may be spatially separated, as antigen-laden, activated DCs are able to migrate from peripheral tissues through lymphatics to secondary lymph organs where they interact with T cells.

DCs have a unique ability to phagocytose and present exogenous antigens to CD8 ${ }^{+} \mathrm{T}$ cells in the context of MHC Class I, a process termed cross-presentation[1]. Crosspriming of $\mathrm{CD}^{+} \mathrm{T}$ cells occurs when the DCs are activated by PRR ligation or in the presence of $\mathrm{T}$ cell help[2], a mechanism important in viral and tumor immunity (Figure 1).

In addition to their critical role in adaptive immunity, DCs play a non-redundant role in innate immunity. Their ability to detect pathogen and elaborate cytokines facilitates the activation of innate immune cells including innate lymphoid cells (ILCs)[3], Natural Killer (NK) cells[4] and neutrophils[5], to limit the spread of pathogens during the initiation of adaptive immune mechanisms (Figure 1).

\section{Tolerance}

An alternative outcome of DC:T cell interaction is tolerance (reviewed in [6]). Owing to continuous steady-state migration of tissue DCs to lymph organs[7], this is likely to be the predominant type of encounter in health. In the absence of DC activation, antigen presentation or cross-presentation results in the functional inactivation, anergy or deletion of CD4 or CD8 T cells, respectively([8],[9]). Ligation of T cell associated coinhibitory molecules including CTLA4 or PD-1 by B7 molecules or PD-L1/L2, provides additional inhibitory signals[10]. DC secretion of inhibitory cytokines, such as TGF $\beta$, triggers up regulation of T cell Foxp3 and generation of regulatory $T$ cells (Tregs)[11], which reciprocally maintain a tolerogenic DC phenotype[12]. Secretion of indoleamine 2,3-dioxygenase (IDO) by DCs contributes to tolerance by depleting tryptophan and causing apoptosis of effector $\mathrm{T}$ cells[13]. These mechanisms are important in maintaining peripheral tolerance to self-antigens and commensal microbes but also play a role in thymic central tolerance[14]. In the thymus, migratory DCs present selfantigen from the periphery[15] and resident DCs present blood-derived and tissuespecific antigens from medullary thymic epithelial cells[16], for the elimination of selfreactive $T$ cells and induction of natural Tregs[17].

\section{DC subsets}

Similarly to T cells, 'division of labour' is provided by the existence of several different types of DC. Due to their expression of particular PRRs and secretion of specialized cytokines, these subsets respond preferentially to pathogens and differentially polarize $\mathrm{T}$ cells. This allows a large repertoire of responses to antigenic stimuli in the initiation 
and regulation of immunity and tolerance. Flexibility is also conferred by phenotypic and functional plasticity dependent on anatomical location and the microenvironment.

Plasmacytoid DC (pDC) and two subsets of myeloid or conventional/classical DC (cDC) are defined by cross-species gene expression studies and classified in a recent consensus study primarily based on ontogeny, with anatomical location and surface antigen expression added as further refinement[18] (Figure 2).

Human pDC express CD123, CD303 and CD304 but are negative for cDC markers CD11c and CD33. CDC1 are characterized by high expression of CD141, Clec9A, XCR1 and BTLA but lower CD11c, while CDC2 have high levels of CD11c, CD1C, CD2, SIRPA and lower CD141. Heterogeneity has recently been shown within the cDC2[19] and pDC compartments, with the latter containing CD123+ ${ }^{+} \mathrm{CDC}$ precursor cells[20].

\section{DC development and function}

Haematopoietic lineage specification, including DC development, is driven by the expression of specific transcription factors (TFs). TFs may act in multiple lineages, at different stages of differentiation, with additional functional roles in mature cells.

Lineage and stage specific control of expression is governed by master TFs and coactivators, acting at promoter and enhancer elements. Precise regulation of expression may be facilitated by a complex structure of multiple enhancers termed 'super-enhancers' (SE)([21],[22]). In contrast to haplosufficient heterozygous variants, single-nucleotide polymorphisms associated with autoimmune diseases in GWAS studies are enriched in SE regions[23]. Similarly, gene mutations causing disease through haploinsufficiency, compared to autosomal recessive mutations, are enriched for SE architecture and more likely to encode transcription factors[24]. TFs with superenhancer structure may, therefore, be sensitive to gene dosage effects, which result in developmental or functional consequences sufficient to cause disease in the haploinsufficient state.

Dendritic cell specification occurs independently of monocyte development in the steady state. The existing mouse model, whereby DCs develop sequentially through a macrophage-DC progenitor (MDP) and common DC progenitor (CDP), has not been supported by recent work in human[25] and is discordant with contemporary models of haematopoiesis in which lineage priming is observed early in development([26],[27] [28]).

\section{$p D C$}

Differentiation of pDC requires GATA2, PU.1, IRF8, E2-2 (TCF4), ZEB2 and suppression of Id2([29],[30],[31],[32]). pDC are able to respond to viral infection, expressing TLR7 and TLR9 to sense single stranded RNA and double-stranded DNA, respectively[33]. In response, they produce large quantities of type I interferon, mainly IFN $\alpha$, through IRF7 signal transduction[34]. They can also secrete TNF and IL-6 through NF- $\mathrm{KB}$ signaling pathways. $\mathrm{pDC}$ are able to prime CD4 T cells[35] but are also able to induce Tregs through the expression of inducible $\mathrm{T}$ cell Costimulator ligand (ICOS-L)[36] and IDO[37]. They play a role in humoral immunity through the support of $B$ cell functions[38] including $B$ cell activation and proliferation[39], plasma cell differentiation([40],[41]), class-switching[42] and immunoglobulin secretion[43] (Figure 2). 
cDC1 lineage specification is dependent on GATA2, PU.1, Id2, BATF3 and high levels of IRF8([30],[44],[45],[46]). CDC1 are specialized for defense against viruses, intracellular pathogens and tumors, through their enhanced ability to cross-present antigen to $\mathrm{CD}^{+}{ }^{+} \mathrm{T}$ cells and drive Th1 responses. Antigen cross-presentation is enabled by expression of TLR3 and CLEC9A and co-localisation of these PRRs within early endosomes. Engagement of TLR3 by viral double stranded RNA triggers type I interferon production and antigen cross-presentation[47]. CLEC9A is a necrotic cell receptor, which directs cell-associated antigens into the cross-presentation pathway[48]. Further specialized defenses against intracellular pathogens include the elaboration of IL-12, resulting in Th1 polarization and activation of NK cells to form the IL-12/IFN $\gamma$ axis (Figure 2). Expression of XCR1 and secretion of CXCL9/10 allows coordination of XCL1-producing, CXCR3-expressing activated $\mathrm{T}$ and NK cell cytotoxic responses([49],[50]). They also play a role in tolerance, potentiated by the ability to secrete TGF $\beta[51]$ and the expression of BTLA, which engages HVEM on T cells to promote CD5 expression and peripheral Treg induction[52].

\section{cDC2}

Similarly to pDC and $\mathrm{CDC} 1, \mathrm{cDC} 2$ require GATA2 and PU.1 for development, but lineage specification also requires Zeb2 and IRF4([53],[54],[32]). Heterogeneity has been described in the $\mathrm{CDC} 2$ population in both mice and humans. Murine heterogeneity is influenced by tissue site and TF dependence including KLF4 and $\mathrm{NOTCH} 2[55]$. Phenotypic and functional heterogeneity in human blood cDC2 has been demonstrated by transcriptomics[56] and surface expression of CD5[19], but the influence of TFs on development has not been elucidated.

cDC2 express a large repertoire of TLRs (TLR2, 4, 5, 6, 8), NLRs, RLRs and lectins, equipping them to respond to a wide range of pathogens. Consequently, they can produce many cytokines, including IFN $\alpha$, IL-23, IL-1, TNF and IL-8. Unlike their murine counterparts, they are able to secrete large quantities of IL-12 and can cross-present antigen in vitro as efficiently as cDC1, when appropriately activated[57]. cDC2 can induce Th1, Th2 or Th17 responses, suggesting functional plasticity in vivo (Figure 2). DC Inhibitory Receptor 2+ (DCIR2+) cDC2 have been shown to induce tolerance[58] in mice.

\section{Tissue DCs and Langerhans Cells}

In most tissues, populations analogous to blood $\mathrm{CDC1}$ and $\mathrm{cDC} 2$ can be distinguished([59],[18]), but pDC are frequently only found in inflammation. In lymphoid tissue, cDC migrating from tissues (migratory DCs) can be distinguished from blood-derived 'resident DCs' by their differential expression of HLA-DR and CD11c([60],[61]). Lymphoid tissue also contains a significant number of pDC, even during quiescence.

Langerhans cells, originating in stratified epithelia and expressing a unique profile of Langerin, CD1a and EpCAM, provided the first example of migratory DC through the identification of phenotypically similar cells in skin-draining lymph nodes[62]. Similarly to tissue macrophages and brain microglia, murine LCs are first seeded in tissue by primitive erythro-myeloid precursors from the yolk sac[63]. They persist by local selfrenewal in steady-state[64] but influx of bone-marrow derived monocyte[65] and nonmonocyte precursors[66] can be seen following inflammation[67]. LC self-renewal is observed in human limb transplant experiments[68] but replacement by donor-derived cells is seen following haematopoietic transplantation[69]. Establishment of a LC network is dependent on PU.1, RUNX3, Id2[70] and signaling from IL-34, TGF $\beta$ or 
BMP7[71] (reviewed in[72]). The function of LCs is to maintain tolerance to commensals but detect and respond to pathogens, features which have been demonstrated in murine models and in vitro([73],[74],[75],[76]).

\section{Predicted effects of DC deficiency}

Murine models of constitutive and inducible DC depletion and lineage-restricted transcription factor knockouts have helped delineate the non-redundant functions of DCs in vivo; their roles in different immune responses, defense against pathogens and in tolerance (reviewed in[77]). Selective pressure has maintained many conserved elements of immunity between species[78], although identities of cellular phenotype and function are not always maintained at high resolution.

Simple extrapolation from DC-deficient mice challenged with specific pathogens predicts that absolute DC deficiency would lead to complex immunodeficiencies and immune dysregulation. Lack of DCs should cause deficient NK cell and ILC activation with defective T cell responses due to weak TCR signaling and loss of co-stimulatory support. This in turn should lead to deficient responses to viruses, intracellular pathogens and immunosurveillance to cancer. Impairment of tolerogenic mechanisms would also be predicted to cause autoimmunity or loss of mucosal immune homeostasis.

More subtle effects, or pathogen-specific susceptibity, might be seen in the context of depletion or dysfunction of a particular DC subset. For example, disruption of the IL$12 / \mathrm{IFN} \gamma$ axis associated with loss of cDCs or monocytes would be predicted to compromise immunity to mycobacteria while lack of pDC would adversely affect antiviral and respiratory pathogen responses and reduce B cell support for the development of robust humoral immunity([79],[80]).

\section{Quantitative DC Immunodeficiencies}

In the context of PID, DCs may be reduced in number, defective in function, or both. Two syndromes associated with absolute monocyte and DC deficiency have been described; heterozygous GATA2([81],[82]) and bi-allelic IRF8 mutations([83],[84]). A more subtle DC deficiency is associated with heterozygous IRF8 mutation[83] and IKZF1 haploinsufficiency(Cytlak et al., 2017 in review) (Table 1).

\section{GATA2 haploinsufficiency}

GATA2 is a member of the GATA-binding transcription factor family and is essential for the maintenance of haematopoietic stem cells (HSC). Outside the haematopoietic system, GATA2 is expressed in endothelial cells[85] and the central nervous system([86],[87]). GATA2 haploinsufficiency results in attrition of HSC and progression to myelodysplasia and acute myeloid leukaemia, associated with accumulation of additional genetic defects, commonly monosomy 7, trisomy 8, ASXL1 or SETBP1 mutations. In keeping with the observation that monogenic haploinsufficient diseases enrich for transcription factors containing super-enhancer regions[24], GATA2 possesses a $40 \mathrm{~kb}$ SE region found at $-110 \mathrm{~kb}$ from the transcription start site. This region is also implicated in the pathogenesis inv(3)/t(3:3) AML where its translocation to the EVI1 gene results in up regulation of EVI1 but haploinsufficiency of GATA2[88]. There is a wide range of age and phenotypes at presentation but a high penetrance with $90 \%$ of carriers showing symptoms by the age of $60 \mathrm{yrs}$. A number of syndromes have described these features including familial MDS/AML, Emberger's (deafness, lymphedema and MDS/AML) and MonoMAC (monocytopenia with mycobacterium avium complex). Extra-hematopoietic effects may manifest as primary lymphoedema, dysmorphia or sensorineural deafness. 
Prior to the development of classical MDS/AML, immunodeficiency associated with failure of mononuclear cell differentiation, resulting in dendritic cell, monocyte and lymphoid deficiency (DCML deficiency) in blood and tissues, is recognized in many patients. The failure to replenish lymphocytes from bone marrow results in a predominance of memory or terminally differentiated B, T and NK cells in blood. The presence of plasma cells in tissues, preserved immunoglobulin levels and memory $\mathrm{T}$ cells affords ongoing immunity to previously encountered antigens but the ability to mount effective adaptive immune responses to novel pathogens is critically impaired. Interestingly, tissue macrophages and epidermal Langerhans cells are preserved, in keeping with their longevity or independence from bone marrow derived precursors. The decline in mononuclear cells can be tracked over decades, during which there is a predisposition to autoimmunity (hepatitis, erythema nodosum), pulmonary alveolar proteinosis, infections (atypical mycobacteria, herpes virus and fungal pathogens) and cancer, particularly HPV/EBV-driven malignancies (Figure 3).

It remains unclear whether DCML deficiency and impaired immunity is an invariant finding or whether MDS/AML can occur de novo, particularly in children.

\section{IRF8 mutation}

IRF8, a member of the interferon regulatory factor family, is a haematopoietic TF, also known as interferon consensus sequence binding protein (ICSBP), with important roles in development and the function of mature cells of both myeloid and lymphoid lineages([89],[90],[91]).

Two patients are described with bi-allelic IRF8 mutations; homozygous K108E mutation[83] and compound heterozygous R291Q and R83C mutations[84]. Both presented in infancy with infective symptoms, proliferation of granulocytes and absent DCs and monocytes. The infant carrying homozygous $\mathrm{K} 108 \mathrm{E}$ mutations received neonatal BCG vaccine and presented with BCG-osis. The recently described patient with compound heterozygous mutations presented with recurrent respiratory virus infections from the age of 7 weeks. Both required HSCT at the age of 4 months or $4 y$ rs, respectively.

More detailed studies revealed a complex immunodeficiency with phenotypic and transcriptomic perturbations in multiple lineages. The failure of T cells to elaborate Th1 or Th17 cytokines and reduced maturation of $\mathrm{NK}$ and $\mathrm{CD}^{+} \mathrm{T}$ cells likely resulted from insufficient TCR signaling strength in the absence of DCs. This, combined with disruption of the IL-12/IFN $\gamma$ circuit, contributed to infection with intracellular pathogens including low-virulence mycobacterial, mycoplasma and viral infections. Reduced B cell class switching with low IgA levels were in keeping with the supportive role of DCs in humoral immunity.

Lymphoid cell intrinsic effects of IRF8 mutations were seen with reduced frequency and complexity of somatic hypermutation in B cells, consistent with the requirement of IRF8 for the germinal center reaction[92]. In the T cell compartment, increased GMCSF production may have contributed to the granulocyte hyperplasia, driven by the unopposed granulocyte promoting action of $\mathrm{C} / \mathrm{EBP} \alpha$, normally inhibited by IRF8 in bone marrow progenitors.

In both affected individuals, developmental delay with intracerebral calcification was observed in the absence of congenital infection. In mouse, IRF8 is necessary for microglial development[93] and/or function([94],[95]) but whether this, dysregulated interferon responses or as yet undefined mechanisms are responsible, is unknown (Figure 4). 
The murine IRF8 locus has a SE structure with different elements active in CDC1 and pDC lineages[45], consistent with the requirement for precise control of IRF8 levels to determine DC lineage specification[45]. PU.1 dependent IRF8 auto-activation is necessary for the development of murine CDPs and Batf3 is required to maintain IRF8 auto-activation for cDC1 but not pDC differentiation[45]. Haploinsufficiency of genes controlled by SEs frequently causes a cellular and clinical phenotype. Heterozygous T80A mutations have a modest effect on DC development with apparent preservation of $\mathrm{CDC} 1$ and pDC, loss of CDC2 and the appearance of CD11c+CD1c- cells[96]. This unpredicted pattern may represent allele-specific mechanisms not yet elucidated. Additional IRF8 variants localized to the IAD domain (P224L and A201V) result in subtle effects on $\mathrm{cDC1}$ and $\mathrm{pDC}$ but more pronounced effects on NK cell maturation and function[97]. It is highly likely that other IRF8 variants exist with allele-specific effects on haematopoiesis and immunity.

\section{IKZF1 Haploinsufficiency}

IKZF1 (IKAROS) is the founding member of the IKAROS family of TFs, a key regulator of hematopoiesis and a critical factor in murine lymphocyte and plasmacytoid DC development and function[98]. Human IKZF1 haploinsufficiency has recently been described as a cause of common variable immunodeficiency with attrition of $B$ cells, progressive hypogammaglobulinemia, expanded $\mathrm{CD}^{+} \mathrm{T}$ cells, increased risk of bacterial sinopulmonary infections and autoimmunity([99],[100]). pDC deficiency with expansion of $\mathrm{CDC1}$ and reduced non-classical monocytes is an additional cellular phenotype invariably associated with this mutation[101].

IKZF1 is critical for the activity of super-enhancers at genes required for pre-B cell receptor signaling and differentiation, working with $B$ cell master regulators including EBF1 and PAX5[102]. Targets of IKZF1, identified by CHIP-Seq[103], include ID2, suppression of which is necessary for $\mathrm{pDC}$ development and BATF3, required for cDC1 terminal differentiation. De-repression of these loci due to IKZF1 deficiency is consistent with the observed phenotype of absent pDCs but preserved or expanded cDC1s.

pDC deficiency may contribute to the increased risk of bacterial respiratory infection, commensurate with the role of pDC in prompt bacterial clearance and limitation of inflammation in the lung. Lack of pDC support for B cell function and humoral immunity may exacerbate the $B$ cell attrition and progressive hypogammaglobulinemia, despite the presence of plasma cells in tissues. Reduction of the tolerogenic influence of pDC may permit the development of autoimmunity (Figure 5).

\section{Other disorders associated with pancytopenia}

Other primary immunodeficiencies and secondary bone marrow failure syndromes result in dendritic and monocyte deficiency. Mutations in adenylate kinase 2 (AK2), causing reticular dysgenesis, result in severe pancytopenia, which includes monocyte, dendritic cell and lymphoid lineages([104],[105]). CXCR4 mutations, causing WHIM (warts, hypogammaglobulinaemia, infections and myelokathexis), prevent leukocytes leaving the bone marrow, resulting in peripheral deficiency of granulocytes, monocytes and dendritic cells[106]. The functional contribution of antigen presenting cell deficiency to these clinical syndromes has not yet been elucidated. 


\section{Functional DC deficiencies}

DC dysfunction is present in many immunodeficiency syndromes, either through cell intrinsic effects of the mutation or dysregulation of DC interactions with other cells (Table 1).

\section{Bare lymphocyte syndrome}

The lack of antigen presentation in MHC Class II deficiency, or 'bare lymphocyte syndrome type II', caused by mutations in CIITA, RFXANK, RFC5 or RFXAP, results in failure of adaptive immunity with deficient $\mathrm{CD}^{+}{ }^{+} \mathrm{T}$ cell responses and hypogammaglobulinemia with poor specific antibody responses[107]. This SCID-like phenotype is characterized by recurrent bacterial, invasive fungal, chronic viral and intracellular pathogen infections with a life expectancy less than 10 years in the absence of definitive treatment with HSCT[108].

\section{Wiskott-Aldrich Syndrome}

A migratory dendritic cell defect is caused by mutations of the WAS (Wiskott-Aldrich syndrome) gene, encoding for a cytoskeletal protein. An abnormal DC:Tcell immune synapse results in impaired $T$ cell and antibody responses leading to recurrent bacterial and viral infections and autoimmunity[109]. The reported increase in DC cross-presentation and expansion of $\mathrm{CD}^{+} \mathrm{T}$ cells in WASp knockout mice has not been observed in humans[110].

\section{CD40/CD40Ligand deficiency}

Reciprocal expression of CD40 and CD40L facilitates complex cross-talk networks between activated DCs, B- and T-cells. Dependent on the environment and DC subset, CD40 ligation induces activation and cytokine elaboration, driving T helper cell polarization and B cell help. Direct contact with $B$ cells up regulates BAFF and APRIL, inducing B cell class switching and immunoglobulin secretion (reviewed in[111]). CD40 or CD40L deficiency, causes hyper-IgM (HIGM) syndrome types 1 and 3, respectively, with aberrant $\mathrm{B}$ cell class switching and recurrent bacterial respiratory infections. However, unlike other causes of HIGM due to B cell intrinsic mutations, CD40/CD40L deficiency results in defective cell mediated immunity and increased susceptibility to opportunistic infections (reviewed in[112]).

\section{Pitt-Hopkin's Syndrome}

E2-2 (TCF4) is necessary for murine pDC development[113]. Haploinsufficiency of TCF4 in humans causes Pitt-Hopkin's Syndrome, characterized by abnormal craniofacial and neural development, intellectual disability and epilepsy. This is associated with reduced numbers of pDC with defective IFN $\alpha$ production[29]. The relative preservation of a $\mathrm{CD} 123^{+} \mathrm{CD} 45 \mathrm{RA}{ }^{+} \mathrm{CD} 303^{\text {low }}$ population within the $\mathrm{CD} 123^{+}$ pDC gate was recently explained by its definition as DC precursor[20]. In contrast to IKZF1 haploinsufficiency, no additional myeloid cell or B cell intrinsic defects have been described. Although not classified as a primary immunodeficiency, one study reported recurrent, commonly sinopulmonary infection in $35 \%$ of patients[114].

\section{IRF7 deficiency}

IRF7 is necessary for the expression of type I and type III IFN genes in response to virus and is constitutively expressed in pDC[115]. Severe influenza infection and 
failure of IFN type I and III production by leukocytes, including pDCs, was found in a patient carrying compound heterozygous mutations in IRF7. Peripheral blood pDC numbers were preserved[116].

\section{STAT3 loss and gain of function mutations}

STAT3, a member of the 'transducer and activator of transcription' (STAT) TF family, is responsible for cytokine signal transduction to regulate cell cycle, proliferation, differentiation and apoptosis genes. STAT3 dominant negative mutations cause Hyper IgE syndrome (AD-HIES or Job's syndrome) characterized by facial, dental, skeletal and connective tissue abnormalities, eczematous rashes, recurrent skin and pulmonary staphylococcal and mycotic infections with cold-abscess formation. Defective Th17 responses, due to T cell-intrinsic failure of STAT3 up regulation, are implicated in the pathogenesis. STAT3 is necessary for pDC homeostasis in mouse, required for Flt3 dependent E2.2 expression[117], but pDC numbers were normal in humans with HIES[118]. In contrast, reduction in PDC numbers has been described in STAT3 gain of function mutations, characterized by diverse symptoms including autoimmunity and lymphoproliferation[119]. Some consequences of aberrant STAT3 function in DCs may be predicted due to its mediation of Flt3 signaling and signal transduction of cytokines involved in often autocrine regulation of DC activation including IL-6[120], IL-10[121], IL-12[122], IL-23[123] and IL-27[124]. The regulatory role of STAT3 in human and murine DCs was supported by the defective tolerogenic responses to $\mathrm{IL}-10$ and increased production of $\mathrm{IL}-12$ seen in STAT3 deficiency $([118],[125])$.

\section{DOCK8 Deficiency}

DOCK8 (dedicator of cytokinesis 8) deficiency also causes hyper-lgE syndrome but is additionally associated with profound lymphopenia and susceptibility to viral infections. Severe pDC deficiency was observed in two patients who successfully cleared progressive oral herpes labialis infection when treated with systemic IFN $\alpha 2 \beta[126]$. In mouse, NLRP10 deficiency is associated with DC migration defects in

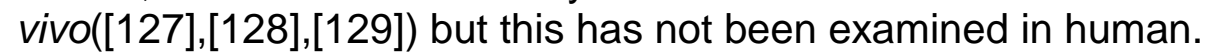

\section{Hermansky-Pudlak syndrome}

Hermansky-Pudlak syndrome is characterized by oculocutaneous albinism, platelet dysfunction and a ceroid storage disorder. A number of types are described, with phenotypic variation related to the underlying genetic mutation. Type 2 is caused by autosomal recessive $A P 3 B 1$ mutations and encompasses an immunodeficiency phenotype with recurrent viral and bacterial infections. $A P 3 B 1$ encodes for the beta3A subunit of AP-3 (adaptor protein 3) complex, involved in cargo-specific transport of proteins from endosomes to lysosomes. Defects in cytotoxic T and NK cells have been described[130]. Defects have also been shown in CD1-dependent antigen presentation[131], TLR7/9 dependent secretion of type I interferon by plasmacytoid DCs[132] and delayed maturation and cytokine secretion by monocyte-derived DCs[133].

The multi-lineage and multi-level influence exerted by transcription factors and the 'cross-lineage' expression of functional molecules suggests that single gene defects are likely to affect more than one lineage or immune function. DC, lymphoid and myeloid cells all share common origins and the term 'complex immunodeficiency' has 
come to denote defects involving multiple immune cells and their functions. Syndromes associated with neutropenic states may result from mutations in genes also found to be important in murine DC development such as GFI1[134] and ELANE[135]. Similarly, genetic mutations implicated in the B- or T- cell dysfunctions of combined or variable immunodeficiencies may affect DC function including TLR3[136], TRAF3[137], ADA[138] or JAK3[139]. Genes with important roles in DC differentiation or function have recently been identified as novel candidate PID-causing genes, based on their biological proximity to known causative genes, through analysis of the "human gene connectome'([140],[141]).

PID provides the opportunity to interrogate the influence of single genes on DC differentiation and function and the non-redundant roles of DC in vivo. Complementarily, recognition of the involvement of DCs in the pathophysiology of PID provides opportunity for novel interventions in these complex syndromes. The central role of DCs in tolerance and immunity, predicts that complex immunodeficiency states involving DCs will continue to feature significantly among newly discovered PID disorders. 
Figure 1: DC:T cell interactions

DCs may present endogenous antigen in the context of MHC Class I (MHCl) for presentation to $\mathrm{CD}^{+} \mathrm{T}$ cells, or Class II (MHCII) for presentation to $\mathrm{CD} 4^{+} \mathrm{T}$ cells. Endogenous or intracellular pathogen-derived proteins undergo cytosolic proteosomal degradation before loading onto $\mathrm{MHCl}$ in the endoplasmic reticulum (ER) and transport to the surface. Peptides presented in the context of MHC class II are derived largely through proteolytic degradation in the endosome. These peptides may be derived from exogenous material entering the cell through endocytosis, or endogenous proteins internalized in the endosome by autophagy. Alternatively, DCs may crosspresent exogenous antigen in the context of $\mathrm{MHCl}$. Phagocytosis internalizes exogenous antigen into the phagosome where it may be degraded and loaded directly onto $\mathrm{MHCl}$ (vacuolar pathway) or exported to the cytosol for proteosomal degradation (cytosolic pathway) and $\mathrm{MHCl}$ loading in the ER or re-importation to the phagosome. TLR recognition of pathogen associated molecular patterns (PAMPs) induces the recruitment of signal transduction complexes, the activation of signaling pathways to regulate inflammatory and immune gene sets, elaborate cytokines and up regulate costimulatory molecules. Activation of the DC in this way provides co-stimulatory and cytokine driven signals to induce $T$ cell immunity. Recognition of presented antigen by the TCR in the absence of co-stimulation or in the presence of co-inhibitory signals results in T regulatory cell generation or T cell anergy/apoptosis.

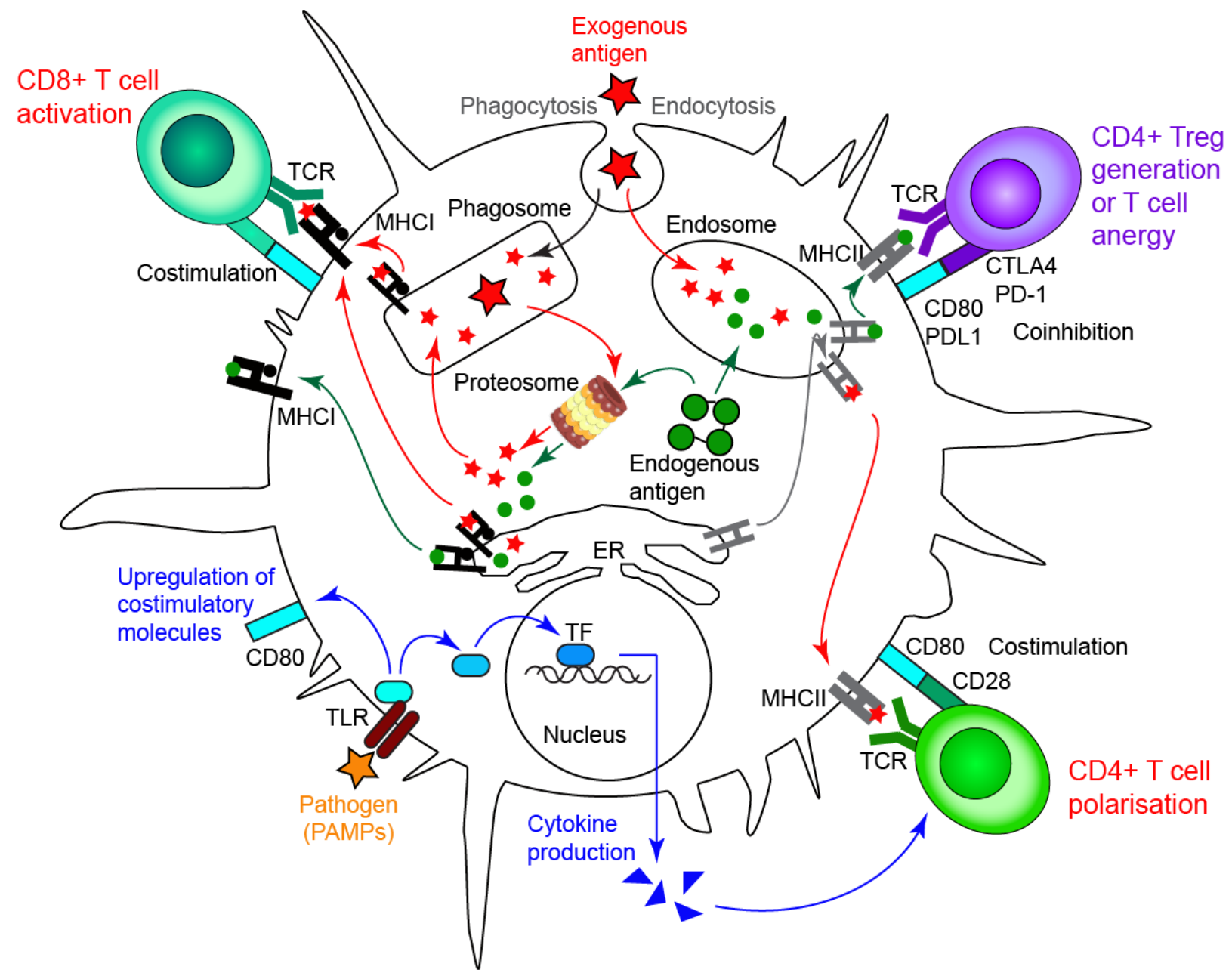


Figure 2: DCs in immunity

Dendritic cells orchestrate the immune response to pathogens and regulate tolerance. Although best known for their initiation of adaptive immunity, they have additional nonredundant roles in innate immunity. Specialized functions, often conferring pathogenspecific immunity, may be performed by particular DC subsets, although likely developmental and functional plasticity exists. Th1 responses and cytotoxic CD8 ${ }^{+}$and NK cell functions are required for defense against intracellular pathogens and tumor. CDC1 claim specialization for antigen cross-presentation and both $\mathrm{CDC} 1$ and $\mathrm{CDC} 2$ can elaborate IL-12 to support IFN $\gamma$ production. Th2 and Th17 responses are more commonly associated with CDC2 activation, which may also result in elaboration of neutrophil chemotractants or stimulants. Heterogeneity exists within the cDC2 population which may include cells developmentally relation to monocytes. Inflammatory monocyte-derived DCs resemble CDC2s by a number of surface markers. pDC are specialized to produce large amounts of anti-viral IFN $\alpha$ and maintain humoral immunity through support of $B$ cell functions.

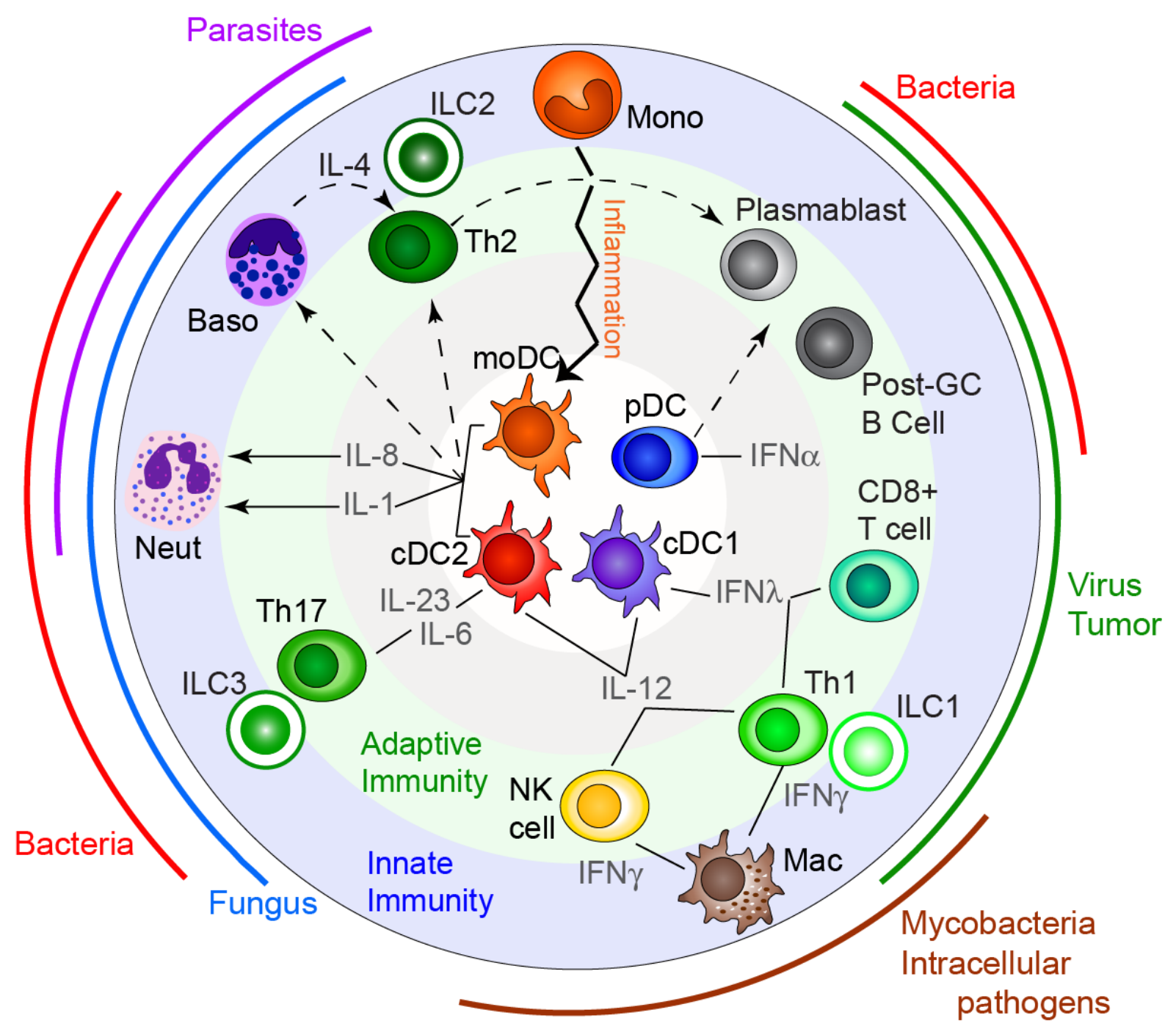


Figure 3: GATA2 deficiency

Heterozygous mutations in GATA2 result in protean clinical syndromes and symptoms. In the hematopoietic compartment, there is attrition of dendritic cells, monocytes, B and NK cells (DCML deficiency) resulting in a period of immunodeficiency with some immunity maintained by the persistence of memory cells and preservation of tissue macrophages and Langerhans cells. During this phase, symptoms may include autoimmunity (hepatitis, pannicluitis, erythema nodosum), infection with nontuberculous mycobacteria (MonoMAC syndrome), sino-pulmonary infections, warts, HPV-related neoplasia and pulmonary alveolar proteinosis. There is a high risk of MDS/AML (Familial MDS/AML). Alternative hematopoietic presentations include apparent de novo AML, CMML, aplastic anaemia, autoimmune cytopenias. Extrahematopoietic effects include sensorineural deafness and primary lymphedema (Emberger's Syndrome: primary lymphedema, deafness and MDS). Absence of cell represents complete deficiency, faded cells represent reduced numbers; red cell outline represents abnormal phenotype or function.

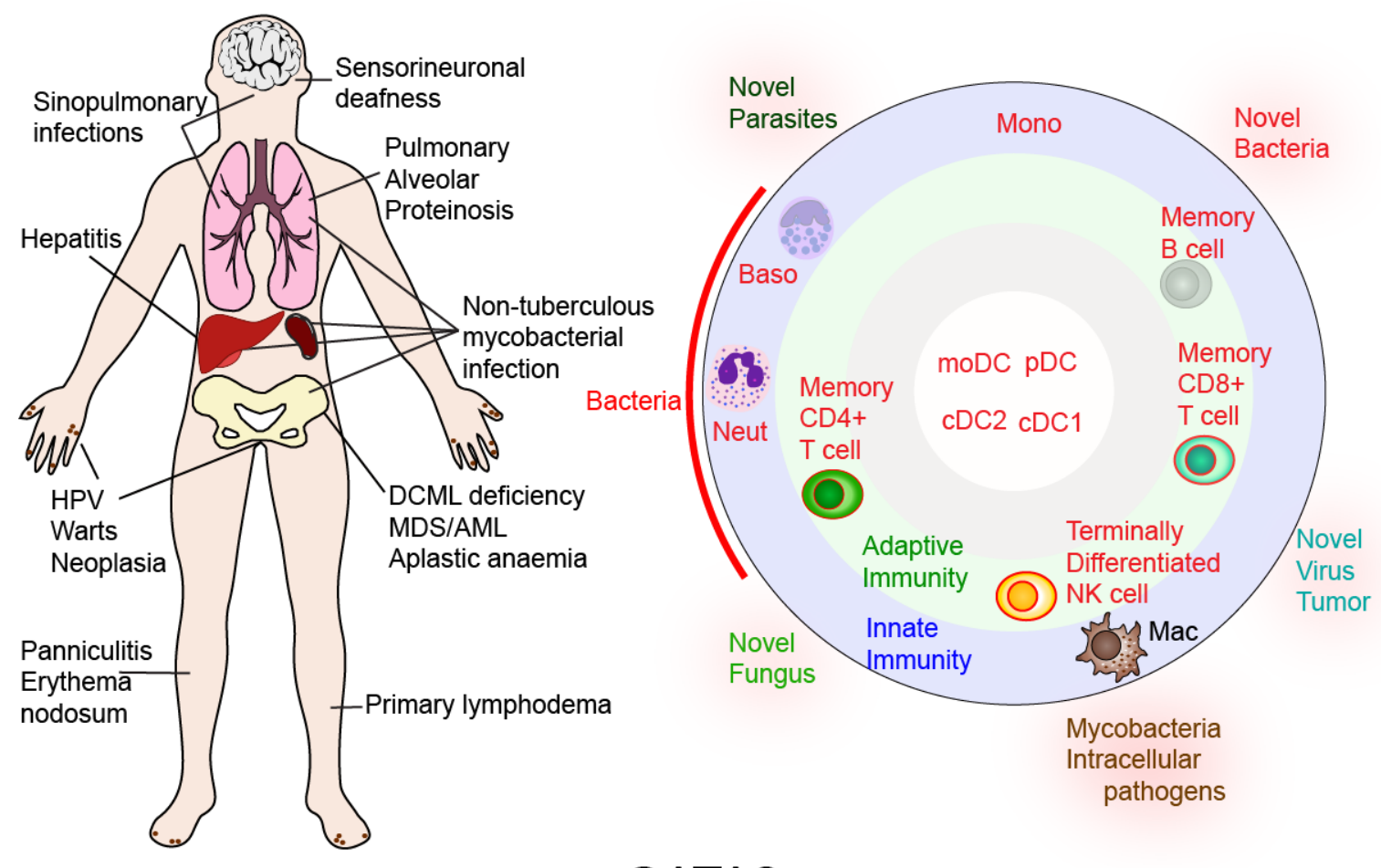


Figure 4: Bi-allelic IRF8 deficiency

The two reported cases carrying bi-allelic IRF8 mutation presented in infancy with vaccination-related BCG-osis (homozygous K108E mutation) or severe respiratory viral infections (compound heterozygous R291Q and R83C mutations). Proliferation of granulocytes but near absence of monocytes and DCs was observed in both patients. There was a reduction in $\mathrm{CD} 4^{+}$and $\mathrm{CD} 8^{+}$memory cells and deficient Th1 and Th17 T cell responses. There was evidence for reduced somatic hypermutation in peripheral blood B cells and low IgA levels. Tissue macrophages and Langerhans cells were preserved. Absence of cell represents complete deficiency, faded cells represent reduced numbers; red cell outline represents abnormal phenotype or function.
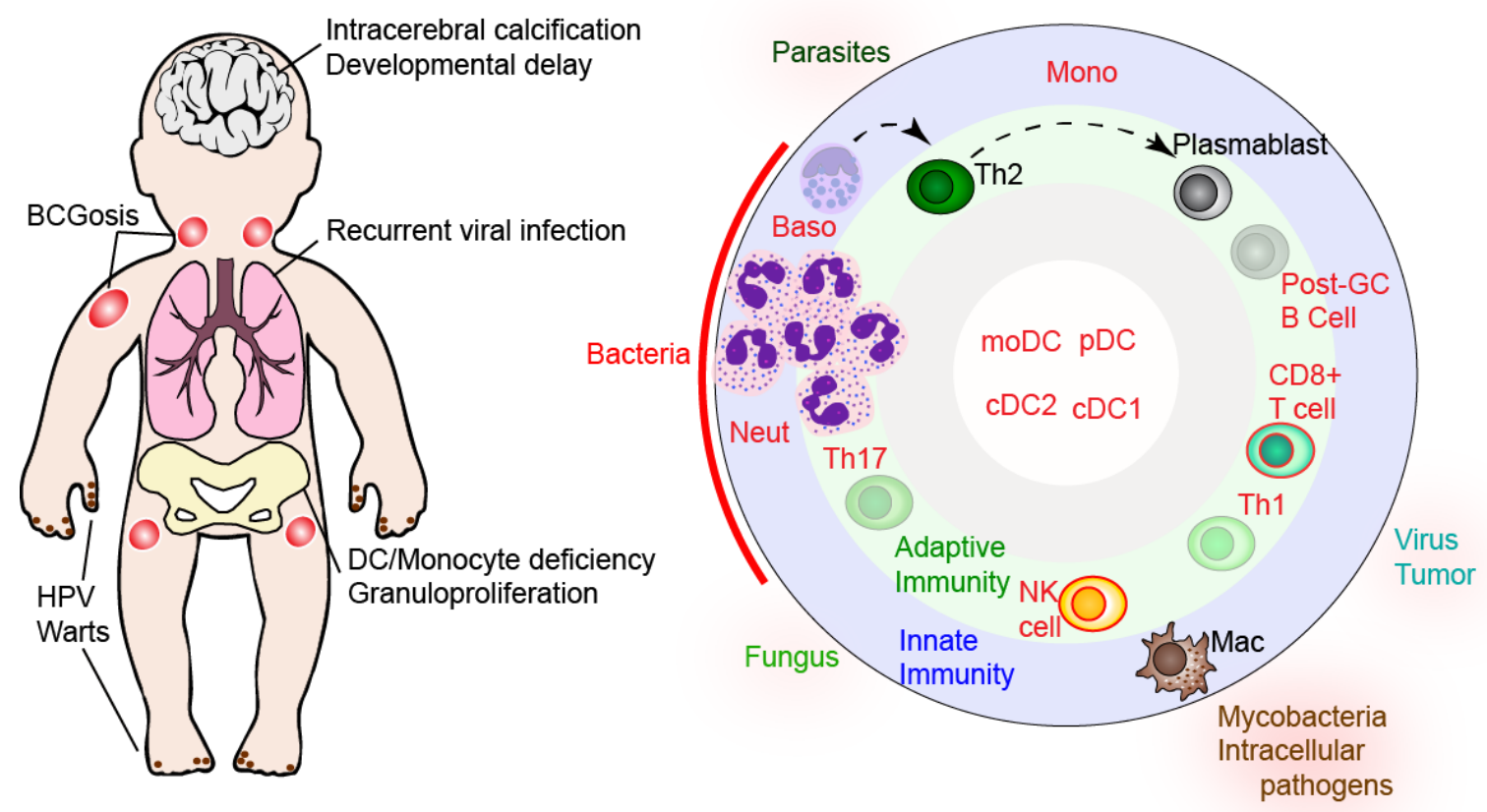
Figure 5: IKZF1 haploinsufficiency

IKZF1 (IKAROS) mutation results in a variably penetrant immunodeficiency characterized by progressive attrition of B cells, hypogammaglobulinemia, recurrent bacterial sinopulmonary infections and autoimmunity. In the DC compartment, pDC deficiency but expansion of $\mathrm{CDC} 1$ is seen, implicating IKZF1 in the homeostasis of DC subset development. Functional DC defects include failure of IFN $\alpha$ elaboration from pDC and reduced IL-12 production in response to TLR7/8 ligation. Absence of cell represents complete deficiency, faded cells represent reduced numbers; large cell represents expanded numbers, red cell outline represents abnormal phenotype or function.
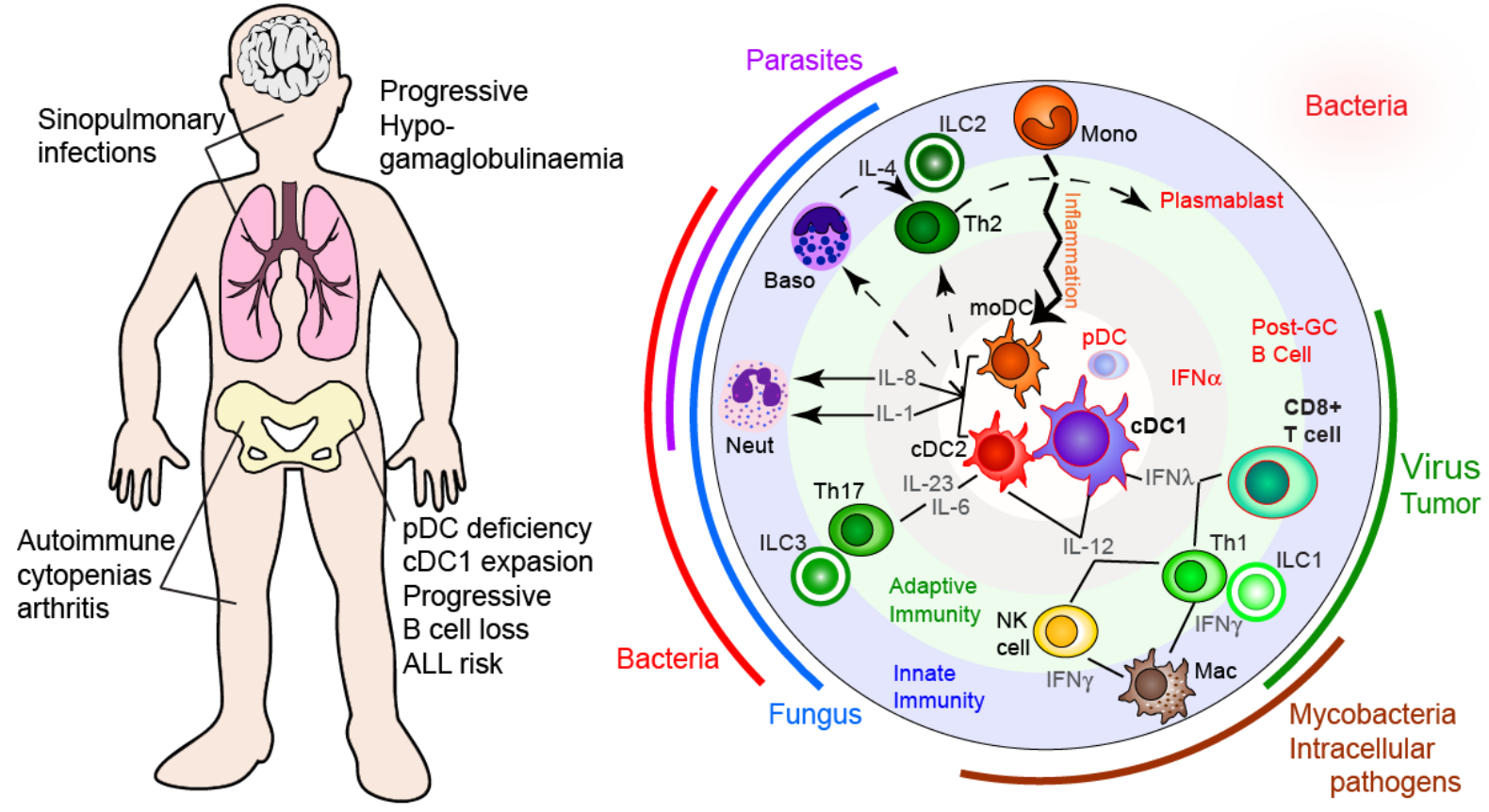
Table 1: Summary of DC deficiencies in PID

Summary of the genetic defects, clinical and cellular phenotypes found in PIDs known to encompass DC deficiency or dysfunction.

\begin{tabular}{|c|c|c|c|c|}
\hline & Gene & Clinical phenotype & Cell phenotype & DC Phenotype \\
\hline \multirow{3}{*}{ Deficiency } & Bi-allelic IRF8 & $\begin{array}{l}\text { Mycobacterial and viral infection } \\
\text { Intracerebral calcification and developmental delay }\end{array}$ & $\begin{array}{l}\text { Loss of all monocyte and DC subsets. Impaired } \\
\text { Th1 and Th17. Myeloproliferation. }\end{array}$ & $\begin{array}{c}\text { Complete absence of DCs/monocytes but preservation } \\
\text { of tissue macrophages and LCs }\end{array}$ \\
\hline & Heterozygous GATA2 & $\begin{array}{l}\text { Mycobacterial, viral (HPV) infection. Lymphodema, } \\
\text { deafness, autoimmunity, malignancy, MDS/AML }\end{array}$ & \begin{tabular}{|c|}
$\begin{array}{c}\text { Denditic cell, monocyte, B and NK Iymphoid } \\
\text { (DCML) deficiency }\end{array}$ \\
\end{tabular} & $\begin{array}{l}\begin{array}{c}\text { Complete absence of DC/monocyte but preservation of } \\
\text { tissue macrophages and LCs }\end{array} \\
\end{array}$ \\
\hline & Heterozygous IKZF1 & $\begin{array}{c}\text { Sino-piulmonary infections, autoimmunity, susceptibility } \\
\text { to acute lymphoblastic leukemia }\end{array}$ & $\begin{array}{l}\text { Progressive loss of } B \text { cells and immunoglobulins, } \\
\text { expanded } C D 8+T \text { cells. }\end{array}$ & $\begin{array}{l}\text { Deficient plasmacytoid DCS, expanded CDC1. Reduced } \\
\text { IFNa and IL-12 production }\end{array}$ \\
\hline \multirow{2}{*}{ Pancytopenia } & AK2 (Reticular dysgenesis) & \begin{tabular}{|c|} 
Neonatal fatal septicaemia \\
Hypoplasia of Iymphoid organs \\
\end{tabular} & Global leukocytopenia & Global loss of monocytes, DCs and LCs \\
\hline & CXCR4 (WHIM) & Warts (HPV), recurrent bacterial infections, carcinomas & $\begin{array}{c}\text { B cell lymphopenia (hypogammaglobulinemia), } \\
\text { Myelokathexis with neutropenia }\end{array}$ & Reduced numbers of monocytes and DCs \\
\hline \multirow{9}{*}{ Dysfunction } & $\begin{array}{c}\text { Bare lymphocyte syndrome: MHC Class II deficiency. } \\
\text { CIITA, RFXANK, RFX5, RFXAP mutations }\end{array}$ & \begin{tabular}{|c|}
$\begin{array}{l}\text { Failure to thrive, diarrhoea, respiratory tract infections, } \\
\text { liverbililiary tract disease }\end{array}$ \\
\end{tabular} & Loss of MHC Class II expression on leukocytes & $\begin{array}{l}\text { Deficient antigen presentation and failure to mount } \\
\text { effective } C D 4+T \text { cell responses }\end{array}$ \\
\hline & WASp (Wiskott-Aldrich Syndrome) & $\begin{array}{c}\text { Thrombocytopenia, bacterial and viral infections, atopia, } \\
\text { autoimmunity, IgA nephropathy, Iymphoma }\end{array}$ & Progressive reduction in $\mathrm{T}$ cells & \begin{tabular}{|l} 
Cytoskeletal protein; affects DC migration and DC:T cell \\
immune synapse. Impaired T cell and antibody \\
responses
\end{tabular} \\
\hline & $\mathrm{CD} 40 / \mathrm{CD} 40 \mathrm{~L}$ & $\begin{array}{l}\text { Opportunistic infections. Gastrointestinal and liver/biliary } \\
\text { tract disease. }\end{array}$ & $\begin{array}{c}\text { Defective class switching: IgM+and } \lg \mathrm{D}+\mathrm{B} \text { cells } \\
\text { only. Neutropenia }\end{array}$ & $\begin{array}{l}\text { Impaired DC signaling cytokine production and cross- } \\
\text { presentation }\end{array}$ \\
\hline & TCF4/E2-2 (Pitt-Hopkins Syndrome) & \begin{tabular}{|c|}
$\begin{array}{c}\text { Recurrent infections in } 35 \% \text { of patients. Distinct facial } \\
\text { features, epilepsy, intellectual disability }\end{array}$ \\
\end{tabular} & Low IgM & Impaired pDC IFNa responses in vitro \\
\hline & STAT3 gain of function & $\begin{array}{l}\text { Lymphoproliferation, autoimmunity (cytopenias and } \\
\text { solid organ), infections, short stature }\end{array}$ & $\begin{array}{c}\text { Variable T cell Iymphopenia, reduced CD4-CD8- } \\
\text { TCR } 1+\text { T cells }\end{array}$ & Reduced plasmacytoid DCs \\
\hline & STAT3 loss of function (Hyper lgE) & $\begin{array}{c}\text { Bacterial (S aureus), aspergillus, Pneumocystiss jirovecii, } \\
\text { mucocutaneous candidiasis, tacial, dentala, skeletal and } \\
\text { connective tissue abnormalities }\end{array}$ & $\begin{array}{l}\text { Reduced B cells, elevated IgE with decreased } \\
\text { specific antibodies }\end{array}$ & Impaired IL-10 responses in DCs \\
\hline & DOCK8 deficiency (Hyper lgE) & \begin{tabular}{c|} 
Recurrent infections, cutaneous viral and \\
staphylococcal infections,atopy, susceptibility to cancer
\end{tabular} & $\begin{array}{l}\text { Impaired T cell proliferation, Treg deficiency. Low } \\
\text { CD27+ memory B cells, decreased NK cells }\end{array}$ & Severe $\mathrm{PDC}$ deficiency \\
\hline & Bi-allelic IRF7 & Severe influenza infection in childhood & No defects reported & Impaired IFN types I and III production from pDC \\
\hline & Hermansky-Pudlak Syndrome type II (AP3B1 mutation) & Recurrent viral and bacterial infections & $\begin{array}{c}\text { Impaired NK and CD8+ T cell cytotoxicity and } \\
\text { degranulation }\end{array}$ & $\begin{array}{l}\text { Defects in CD1 antigen presentation and type I } \\
\text { interferon secretion from plasmacytoid DCs }\end{array}$ \\
\hline
\end{tabular}

\section{Funding}

This work was supported by The Wellcome Trust (VB, UC; award number 101155/Z/13/Z) and Bright Red (VB, MC). 


\section{References}

1 Carbone, FR, Bevan, MJ. Class I-restricted processing and presentation of exogenous cell-associated antigen in vivo. J Exp Med. 1990;171(2):377-387.

2 Heath, WR, Carbone, FR. Cross-presentation in viral immunity and self-tolerance. Nat Rev Immunol. 2001;1(2):126-134.

3 Sonnenberg, GF, Artis, D. Innate lymphoid cells in the initiation, regulation and resolution of inflammation. Nat Med. 2015;21(7):698-708.

4 Harizi, H. Reciprocal crosstalk between dendritic cells and natural killer cells under the effects of PGE2 in immunity and immunopathology. Cell Mol Immunol. 2013;10(3):213-221.

5 Schuster, S, Hurrell, B, Tacchini-Cottier, F. Crosstalk between neutrophils and dendritic cells: a context-dependent process. J Leukoc Biol. 2013;94(4):671-675.

6 Audiger, C, Rahman, MJ, Yun, TJ, Tarbell, KV, Lesage, S. The Importance of Dendritic Cells in Maintaining Immune Tolerance. J Immunol. 2017;198(6):22232231.

7 Tomura, M, Hata, A, Matsuoka, S, Shand, FH, Nakanishi, Y, Ikebuchi, R, Ueha, S, Tsutsui, H, Inaba, K, Matsushima, K, Miyawaki, A, Kabashima, K, Watanabe, $\mathrm{T}$, Kanagawa, $\mathrm{O}$. Tracking and quantification of dendritic cell migration and antigen trafficking between the skin and lymph nodes. Sci Rep. 2014;4:6030.

8 Hawiger, D, Inaba, K, Dorsett, Y, Guo, M, Mahnke, K, Rivera, M, Ravetch, JV, Steinman, RM, Nussenzweig, MC. Dendritic cells induce peripheral $\mathrm{T}$ cell unresponsiveness under steady state conditions in vivo. $J$ Exp Med. 2001;194(6):769-779.

9 Kurts, C, Kosaka, H, Carbone, FR, Miller, JF, Heath, WR. Class I-restricted cross-presentation of exogenous self-antigens leads to deletion of autoreactive CD8(+) T cells. J Exp Med. 1997;186(2):239-245.

10 Probst, HC, Muth, S, Schild, $\mathrm{H}$. Regulation of the tolerogenic function of steadystate DCs. Eur J Immunol. 2014;44(4):927-933.

11 Chen, W, Jin, W, Hardegen, N, Lei, KJ, Li, L, Marinos, N, McGrady, G, Wahl, SM. Conversion of peripheral CD4+CD25- naive T cells to CD4+CD25+ regulatory $\mathrm{T}$ cells by TGF-beta induction of transcription factor Foxp3. $J$ Exp Med. 2003;198(12):1875-1886.

12 Schildknecht, A, Brauer, S, Brenner, C, Lahl, K, Schild, H, Sparwasser, T, Probst, $\mathrm{HC}$, van den Broek, M. FoxP3+ regulatory $\mathrm{T}$ cells essentially contribute to peripheral CD8+ T-cell tolerance induced by steady-state dendritic cells. Proc Natl Acad Sci U S A. 2010;107(1):199-203.

13 Mellor, AL, Munn, DH. IDO expression by dendritic cells: tolerance and tryptophan catabolism. Nat Rev Immunol. 2004;4(10):762-774.

14 Brocker, T, Riedinger, M, Karjalainen, K. Targeted expression of major histocompatibility complex (MHC) class II molecules demonstrates that dendritic cells can induce negative but not positive selection of thymocytes in vivo. J Exp Med. 1997;185(3):541-550.

15 Li, J, Park, J, Foss, D, Goldschneider, I. Thymus-homing peripheral dendritic cells constitute two of the three major subsets of dendritic cells in the steady-state thymus. J Exp Med. 2009;206(3):607-622.

16 Hubert, FX, Kinkel, SA, Davey, GM, Phipson, B, Mueller, SN, Liston, A, Proietto, Al, Cannon, PZ, Forehan, S, Smyth, GK, Wu, L, Goodnow, CC, Carbone, FR, Scott, HS, Heath, WR. Aire regulates the transfer of antigen from mTECs to dendritic cells for induction of thymic tolerance. Blood. 2011;118(9):2462-2472.

17 Coquet, JM, Ribot, JC, Bąbała, N, Middendorp, S, van der Horst, G, Xiao, Y, Neves, JF, Fonseca-Pereira, D, Jacobs, H, Pennington, DJ, Silva-Santos, B, Borst, J. Epithelial and dendritic cells in the thymic medulla promote CD4+Foxp3+ regulatory $\mathrm{T}$ cell development via the CD27-CD70 pathway. $J$ Exp Med. 
2013;210(4):715-728.

18 Guilliams, M, Ginhoux, F, Jakubzick, C, Naik, SH, Onai, N, Schraml, BU, Segura, E, Tussiwand, R, Yona, S. Dendritic cells, monocytes and macrophages: a unified nomenclature based on ontogeny. Nat Rev Immunol. 2014;14(8):571578.

19 Yin, X, Yu, H, Jin, X, Li, J, Guo, H, Shi, Q, Yin, Z, Xu, Y, Wang, X, Liu, R, Wang, S, Zhang, L. Human Blood CD1C+ Dendritic Cells Encompass CD5high and CD5low Subsets That Differ Significantly in Phenotype, Gene Expression, and Functions. J Immunol. 2017;198(4):1553-1564.

20 See, P, Dutertre, CA, Chen, J, Günther, P, McGovern, N, Irac, SE, Gunawan, M, Beyer, M, Händler, K, Duan, K, Sumatoh, HRB, Ruffin, N, Jouve, M, GeaMallorquí, E, Hennekam, RCM, Lim, T, Yip, CC, Wen, M, Malleret, B, Low, I, Shadan, NB, Fen, CFS, Tay, A, Lum, J, Zolezzi, F, Larbi, A, Poidinger, M, Chan, JKY, Chen, Q, Renia, L, Haniffa, M, Benaroch, P, Schlitzer, A, Schultze, JL, Newell, EW, Ginhoux, F. Mapping the human DC lineage through the integration of high-dimensional techniques. Science. 2017

21 Whyte, WA, Orlando, DA, Hnisz, D, Abraham, BJ, Lin, CY, Kagey, MH, Rahl, PB, Lee, TI, Young, RA. Master transcription factors and mediator establish superenhancers at key cell identity genes. Cell. 2013;153(2):307-319.

22 Lovén, J, Hoke, HA, Lin, CY, Lau, A, Orlando, DA, Vakoc, CR, Bradner, JE, Lee, TI, Young, RA. Selective inhibition of tumor oncogenes by disruption of superenhancers. Cell. 2013;153(2):320-334.

23 Vahedi, G, Kanno, Y, Furumoto, Y, Jiang, K, Parker, SC, Erdos, MR, Davis, SR, Roychoudhuri, R, Restifo, NP, Gadina, M, Tang, Z, Ruan, Y, Collins, FS, Sartorelli, V, O'Shea, JJ. Super-enhancers delineate disease-associated regulatory nodes in T cells. Nature. 2015;520(7548):558-562.

24 Afzali, B, Grönholm, J, Vandrovcova, J, O’Brien, C, Sun, HW, Vanderleyden, I, Davis, FP, Khoder, A, Zhang, Y, Hegazy, AN, Villarino, AV, Palmer, IW, Kaufman, J, Watts, NR, Kazemian, M, Kamenyeva, O, Keith, J, Sayed, A, Kasperaviciute, D, Mueller, M, Hughes, JD, Fuss, IJ, Sadiyah, MF, MontgomeryRecht, K, McElwee, J, Restifo, NP, Strober, W, Linterman, MA, Wingfield, PT, Uhlig, HH, Roychoudhuri, R, Aitman, TJ, Kelleher, P, Lenardo, MJ, O'Shea, JJ, Cooper, N, Laurence, ADJ. BACH2 immunodeficiency illustrates an association between super-enhancers and haploinsufficiency. Nat Immunol. 2017;18(7):813823.

25 Lee, J, Zhou, YJ, Ma, W, Zhang, W, Aljoufi, A, Luh, T, Lucero, K, Liang, D, Thomsen, M, Bhagat, G, Shen, Y, Liu, K. Lineage specification of human dendritic cells is marked by IRF8 expression in hematopoietic stem cells and multipotent progenitors. Nat Immunol. 2017

26 Notta, F, Zandi, S, Takayama, N, Dobson, S, Gan, OI, Wilson, G, Kaufmann, KB, McLeod, J, Laurenti, E, Dunant, CF, McPherson, JD, Stein, LD, Dror, Y, Dick, JE. Distinct routes of lineage development reshape the human blood hierarchy across ontogeny. Science. 2016;351(6269):aab2116.

27 Paul, F, Arkin, Y, Giladi, A, Jaitin, DA, Kenigsberg, E, Keren-Shaul, H, Winter, D, Lara-Astiaso, D, Gury, M, Weiner, A, David, E, Cohen, N, Lauridsen, FK, Haas, S, Schlitzer, A, Mildner, A, Ginhoux, F, Jung, S, Trumpp, A, Porse, BT, Tanay, A, Amit, I. Transcriptional Heterogeneity and Lineage Commitment in Myeloid Progenitors. Cell. 2015;163(7):1663-1677.

28 Naik, SH, Perie, L, Swart, E, Gerlach, C, van Rooij, N, de Boer, RJ, Schumacher, TN. Diverse and heritable lineage imprinting of early haematopoietic progenitors. Nature. 2013;496(7444):229-232.

29 Cisse, B, Caton, ML, Lehner, M, Maeda, T, Scheu, S, Locksley, R, Holmberg, D, Zweier, C, den Hollander, NS, Kant, SG, Holter, W, Rauch, A, Zhuang, Y, Reizis, 
B. Transcription factor E2-2 is an essential and specific regulator of plasmacytoid dendritic cell development. Cell. 2008;135(1):37-48.

30 Hacker, C, Kirsch, RD, Ju, XS, Hieronymus, T, Gust, TC, Kuhl, C, Jorgas, T, Kurz, SM, Rose-John, S, Yokota, Y, Zenke, M. Transcriptional profiling identifies Id2 function in dendritic cell development. Nat Immunol. 2003;4(4):380-386.

31 Sichien, D, Scott, CL, Martens, L, Vanderkerken, M, Van Gassen, S, Plantinga, M, Joeris, T, De Prijck, S, Vanhoutte, L, Vanheerswynghels, M, Van Isterdael, G, Toussaint, W, Madeira, FB, Vergote, K, Agace, WW, Clausen, BE, Hammad, H, Dalod, M, Saeys, Y, Lambrecht, BN, Guilliams, M. IRF8 Transcription Factor Controls Survival and Function of Terminally Differentiated Conventional and Plasmacytoid Dendritic Cells, Respectively. Immunity. 2016

32 Scott, CL, Soen, B, Martens, L, Skrypek, N, Saelens, W, Taminau, J, Blancke, G, Van Isterdael, G, Huylebroeck, D, Haigh, J, Saeys, Y, Guilliams, M, Lambrecht, BN, Berx, G. The transcription factor Zeb2 regulates development of conventional and plasmacytoid DCs by repressing Id2. J Exp Med. 2016;213(6):897-911.

33 Bao, M, Liu, YJ. Regulation of TLR7/9 signaling in plasmacytoid dendritic cells. Protein Cell. 2013;4(1):40-52.

34 Swiecki, M, Colonna, M. The multifaceted biology of plasmacytoid dendritic cells. Nat Rev Immunol. 2015;15(8):471-485.

35 Takagi, H, Fukaya, T, Eizumi, K, Sato, Y, Sato, K, Shibazaki, A, Otsuka, H, Hijikata, A, Watanabe, T, Ohara, O, Kaisho, T, Malissen, B, Sato, K. Plasmacytoid dendritic cells are crucial for the initiation of inflammation and T cell immunity in vivo. Immunity. 2011;35(6):958-971.

36 Ito, T, Yang, M, Wang, YH, Lande, R, Gregorio, J, Perng, OA, Qin, XF, Liu, YJ, Gilliet, M. Plasmacytoid dendritic cells prime IL-10-producing T regulatory cells by inducible costimulator ligand. J Exp Med. 2007;204(1):105-115.

37 Chen, W, Liang, X, Peterson, AJ, Munn, DH, Blazar, BR. The indoleamine 2,3dioxygenase pathway is essential for human plasmacytoid dendritic cell-induced adaptive T regulatory cell generation. J Immunol. 2008;181(8):5396-5404.

38 Dubois, B, Bridon, JM, Fayette, J, Barthélémy, C, Banchereau, J, Caux, C, Brière, F. Dendritic cells directly modulate $B$ cell growth and differentiation. $J$ Leukoc Biol. 1999;66(2):224-230.

39 Shaw, J, Wang, YH, Ito, T, Arima, K, Liu, YJ. Plasmacytoid dendritic cells regulate B-cell growth and differentiation via CD70. Blood. 2010;115(15):30513057.

40 Arpin, C, Dechanet, J, Van Kooten, C, Merville, P, Grouard, G, Briere, F, Banchereau, J, Liu, Y. Generation of memory B cells and plasma cells in vitro. Science. 1995;268(5211):720-722.

41 Jego, G, Palucka, AK, Blanck, JP, Chalouni, C, Pascual, V, Banchereau, J. Plasmacytoid dendritic cells induce plasma cell differentiation through type I interferon and interleukin 6. Immunity. 2003;19(2):225-234.

42 Reboldi, A, Arnon, TI, Rodda, LB, Atakilit, A, Sheppard, D, Cyster, JG. IgA production requires $B$ cell interaction with subepithelial dendritic cells in Peyer's patches. Science. 2016;352(6287):aaf4822.

43 Poeck, H, Wagner, M, Battiany, J, Rothenfusser, S, Wellisch, D, Hornung, V, Jahrsdorfer, B, Giese, T, Endres, S, Hartmann, G. Plasmacytoid dendritic cells, antigen, and CpG-C license human B cells for plasma cell differentiation and immunoglobulin production in the absence of T-cell help. Blood. 2004;103(8):3058-3064.

44 Jaiswal, H, Kaushik, M, Sougrat, R, Gupta, M, Dey, A, Verma, R, Ozato, K, Tailor, P. Batf3 and Id2 have a synergistic effect on Irf8-directed classical CD8alpha+ dendritic cell development. J Immunol. 2013;191(12):5993-6001.

45 Grajales-Reyes, GE, Iwata, A, Albring, J, Wu, X, Tussiwand, R, Kc, W, Kretzer, 
NM, Briseno, CG, Durai, V, Bagadia, P, Haldar, M, Schonheit, J, Rosenbauer, F, Murphy, TL, Murphy, KM. Batf3 maintains autoactivation of Irf8 for commitment of a CD8alpha(+) conventional DC clonogenic progenitor. Nat Immunol. 2015;16(7):708-717.

46 Ginhoux, F, Liu, K, Helft, J, Bogunovic, M, Greter, M, Hashimoto, D, Price, J, Yin, N, Bromberg, J, Lira, SA, Stanley, ER, Nussenzweig, M, Merad, M. The origin and development of nonlymphoid tissue CD103+ DCs. $J$ Exp Med. 2009;206(13):3115-3130.

47 Széles, L, Meissner, F, Dunand-Sauthier, I, Thelemann, C, Hersch, M, Singovski, S, Haller, S, Gobet, F, Fuertes Marraco, SA, Mann, M, Garcin, D, Acha-Orbea, H, Reith, W. TLR3-Mediated CD8+ Dendritic Cell Activation Is Coupled with Establishment of a Cell-Intrinsic Antiviral State. J Immunol. 2015;195(3):10251033.

48 Schreibelt, G, Klinkenberg, LJ, Cruz, LJ, Tacken, PJ, Tel, J, Kreutz, M, Adema, GJ, Brown, GD, Figdor, CG, de Vries, IJ. The C-type lectin receptor CLEC9A mediates antigen uptake and (cross-)presentation by human blood BDCA3+ myeloid dendritic cells. Blood. 2012;119(10):2284-2292.

49 Ohta, T, Sugiyama, M, Hemmi, H, Yamazaki, C, Okura, S, Sasaki, I, Fukuda, Y, Orimo, T, Ishii, KJ, Hoshino, K, Ginhoux, F, Kaisho, T. Crucial roles of XCR1expressing dendritic cells and the XCR1-XCL1 chemokine axis in intestinal immune homeostasis. Sci Rep. 2016;6:23505.

50 Alexandre, YO, Ghilas, S, Sanchez, C, Le Bon, A, Crozat, K, Dalod, M. XCR1+ dendritic cells promote memory CD8+ T cell recall upon secondary infections with Listeria monocytogenes or certain viruses. J Exp Med. 2016;213(1):75-92.

51 Yamazaki, S, Dudziak, D, Heidkamp, GF, Fiorese, C, Bonito, AJ, Inaba, K, Nussenzweig, MC, Steinman, RM. CD8+ CD205+ splenic dendritic cells are specialized to induce Foxp3+ regulatory T cells. J Immunol. 2008;181(10):69236933.

52 Jones, A, Bourque, J, Kuehm, L, Opejin, A, Teague, RM, Gross, C, Hawiger, D. Immunomodulatory Functions of BTLA and HVEM Govern Induction of Extrathymic Regulatory $\mathrm{T}$ Cells and Tolerance by Dendritic Cells. Immunity. 2016;45(5):1066-1077.

53 Schlitzer, A, McGovern, N, Teo, P, Zelante, T, Atarashi, K, Low, D, Ho, AW, See, P, Shin, A, Wasan, PS, Hoeffel, G, Malleret, B, Heiseke, A, Chew, S, Jardine, L, Purvis, HA, Hilkens, CM, Tam, J, Poidinger, M, Stanley, ER, Krug, AB, Renia, L, Sivasankar, B, Ng, LG, Collin, M, Ricciardi-Castagnoli, P, Honda, K, Haniffa, M, Ginhoux, F. IRF4 transcription factor-dependent CD11b+ dendritic cells in human and mouse control mucosal IL-17 cytokine responses. Immunity. 2013;38(5):970983.

54 Guilliams, M, Dutertre, CA, Scott, CL, McGovern, N, Sichien, D, Chakarov, S, Van Gassen, S, Chen, J, Poidinger, M, De Prijck, S, Tavernier, SJ, Low, I, Irac, SE, Mattar, CN, Sumatoh, HR, Low, GHL, Chung, TJK, Chan, DKH, Tan, KK, Hon, TLK, Fossum, E, Bogen, B, Choolani, M, Chan, JKY, Larbi, A, Luche, H, Henri, S, Saeys, Y, Newell, EW, Lambrecht, BN, Malissen, B, Ginhoux, F. Unsupervised High-Dimensional Analysis Aligns Dendritic Cells across Tissues and Species. Immunity. 2016;45(3):669-684.

55 Murphy, TL, Grajales-Reyes, GE, Wu, X, Tussiwand, R, Briseño, CG, Iwata, A, Kretzer, NM, Durai, V, Murphy, KM. Transcriptional Control of Dendritic Cell Development. Annu Rev Immunol. 2016;34:93-119.

56 Villani, AC, Satija, R, Reynolds, G, Sarkizova, S, Shekhar, K, Fletcher, J, Griesbeck, M, Butler, A, Zheng, S, Lazo, S, Jardine, L, Dixon, D, Stephenson, E, Nilsson, E, Grundberg, I, McDonald, D, Filby, A, Li, W, De Jager, PL, RozenblattRosen, O, Lane, AA, Haniffa, M, Regev, A, Hacohen, N. Single-cell RNA-seq 
reveals new types of human blood dendritic cells, monocytes, and progenitors. Science. 2017;356(6335)

57 Nizzoli, G, Krietsch, J, Weick, A, Steinfelder, S, Facciotti, F, Gruarin, P, Bianco, A, Steckel, B, Moro, M, Crosti, M, Romagnani, C, Stolzel, K, Torretta, S, Pignataro, L, Scheibenbogen, C, Neddermann, P, De Francesco, R, Abrignani, S, Geginat, J. Human CD1C+ dendritic cells secrete high levels of IL-12 and potently prime cytotoxic T-cell responses. Blood. 2013;122(6):932-942.

58 Price, JD, Hotta-Iwamura, C, Zhao, Y, Beauchamp, NM, Tarbell, KV. DCIR2+ cDC2 DCs and Zbtb32 Restore CD4+ T-Cell Tolerance and Inhibit Diabetes. Diabetes. 2015;64(10):3521-3531.

59 Haniffa, M, Shin, A, Bigley, V, McGovern, N, Teo, P, See, P, Wasan, PS, Wang, XN, Malinarich, F, Malleret, B, Larbi, A, Tan, P, Zhao, H, Poidinger, M, Pagan, S, Cookson, S, Dickinson, R, Dimmick, I, Jarrett, RF, Renia, L, Tam, J, Song, C, Connolly, J, Chan, JK, Gehring, A, Bertoletti, A, Collin, M, Ginhoux, F. Human tissues contain CD141hi cross-presenting dendritic cells with functional homology to mouse CD103+ nonlymphoid dendritic cells. Immunity. 2012;37(1):60-73.

60 Segura, E, Valladeau-Guilemond, J, Donnadieu, MH, Sastre-Garau, X, Soumelis, $\mathrm{V}$, Amigorena, S. Characterization of resident and migratory dendritic cells in human lymph nodes. J Exp Med. 2012;209(4):653-660.

61 Ohl, L, Mohaupt, M, Czeloth, N, Hintzen, G, Kiafard, Z, Zwirner, J, Blankenstein, T, Henning, G, Förster, R. CCR7 governs skin dendritic cell migration under inflammatory and steady-state conditions. Immunity. 2004;21(2):279-288.

62 Silberberg, I, Baer, RL, Rosenthal, SA. The role of Langerhans cells in allergic contact hypersensitivity. A review of findings in man and guinea pigs. $J$ Invest Dermatol. 1976;66(4):210-217.

63 Hoeffel, G, Wang, Y, Greter, M, See, P, Teo, P, Malleret, B, Leboeuf, M, Low, D, Oller, G, Almeida, F, Choy, SH, Grisotto, M, Renia, L, Conway, SJ, Stanley, ER, Chan, JK, Ng, LG, Samokhvalov, IM, Merad, M, Ginhoux, F. Adult Langerhans cells derive predominantly from embryonic fetal liver monocytes with a minor contribution of yolk sac-derived macrophages. J Exp Med. 2012;209(6):11671181.

64 Merad, M, Hoffmann, P, Ranheim, E, Slaymaker, S, Manz, MG, Lira, SA, Charo, I, Cook, DN, Weissman, IL, Strober, S, Engleman, EG. Depletion of host Langerhans cells before transplantation of donor alloreactive $T$ cells prevents skin graft-versus-host disease. Nat Med. 2004;10(5):510-517.

65 Ginhoux, F, Tacke, F, Angeli, V, Bogunovic, M, Loubeau, M, Dai, XM, Stanley, ER, Randolph, GJ, Merad, M. Langerhans cells arise from monocytes in vivo. Nat Immunol. 2006;7(3):265-273.

66 Sere, K, Baek, JH, Ober-Blobaum, J, Muller-Newen, G, Tacke, F, Yokota, Y, Zenke, M, Hieronymus, T. Two distinct types of Langerhans cells populate the skin during steady state and inflammation. Immunity. 2012;37(5):905-916.

67 Capucha, T, Mizraji, G, Segev, H, Blecher-Gonen, R, Winter, D, Khalaileh, A, Tabib, Y, Attal, T, Nassar, M, Zelentsova, K, Kisos, H, Zenke, M, Seré, K, Hieronymus, T, Burstyn-Cohen, T, Amit, I, Wilensky, A, Hovav, AH. Distinct Murine Mucosal Langerhans Cell Subsets Develop from Pre-dendritic Cells and Monocytes. Immunity. 2015;43(2):369-381.

68 Kanitakis, J, Morelon, E, Petruzzo, P, Badet, L, Dubernard, JM. Self-renewal capacity of human epidermal Langerhans cells: observations made on a composite tissue allograft. Exp Dermatol. 2011;20(2):145-146.

69 Haniffa, M, Ginhoux, F, Wang, XN, Bigley, V, Abel, M, Dimmick, I, Bullock, S, Grisotto, M, Booth, T, Taub, P, Hilkens, C, Merad, M, Collin, M. Differential rates of replacement of human dermal dendritic cells and macrophages during hematopoietic stem cell transplantation. J Exp Med. 2009;206(2):371-385. 
70 Chopin, M, Seillet, C, Chevrier, S, Wu, L, Wang, H, Morse, HC, Belz, GT, Nutt, SL. Langerhans cells are generated by two distinct PU.1-dependent transcriptional networks. J Exp Med. 2013;210(13):2967-2980.

71 Bobr, A, lgyarto, BZ, Haley, KM, Li, MO, Flavell, RA, Kaplan, DH. Autocrine/paracrine TGF- $\beta 1$ inhibits Langerhans cell migration. Proc Natl Acad Sci U S A. 2012;109(26):10492-10497.

72 Collin, M, Milne, P. Langerhans cell origin and regulation. Curr Opin Hematol. 2016;23(1):28-35.

73 Shklovskaya, E, O'Sullivan, BJ, Ng, LG, Roediger, B, Thomas, R, Weninger, W, Fazekas de St Groth, B. Langerhans cells are precommitted to immune tolerance induction. Proc Natl Acad Sci U S A. 2011;108(44):18049-18054.

74 Seneschal, J, Clark, RA, Gehad, A, Baecher-Allan, CM, Kupper, TS. Human epidermal Langerhans cells maintain immune homeostasis in skin by activating skin resident regulatory T cells. Immunity. 2012;36(5):873-884.

$75 \mathrm{Kim}, \mathrm{JH}, \mathrm{Hu}, \mathrm{Y}$, Yongqing, T, Kim, J, Hughes, VA, Le Nours, J, Marquez, EA, Purcell, AW, Wan, Q, Sugita, M, Rossjohn, J, Winau, F. CD1a on Langerhans cells controls inflammatory skin disease. Nat Immunol. 2016;17(10):1159-1166.

76 Banchereau, J, Thompson-Snipes, L, Zurawski, S, Blanck, JP, Cao, Y, Clayton, S, Gorvel, JP, Zurawski, G, Klechevsky, E. The differential production of cytokines by human Langerhans cells and dermal CD14(+) DCs controls CTL priming. Blood. 2012;119(24):5742-5749.

77 Durai, V, Murphy, KM. Functions of Murine Dendritic Cells. Immunity. 2016;45(4):719-736.

78 Vu Manh, TP, Bertho, N, Hosmalin, A, Schwartz-Cornil, I, Dalod, M. Investigating Evolutionary Conservation of Dendritic Cell Subset Identity and Functions. Front Immunol. 2015;6:260.

79 Crother, TR, Ma, J, Jupelli, M, Chiba, N, Chen, S, Slepenkin, A, Alsabeh, R, Peterson, E, Shimada, K, Arditi, M. Plasmacytoid dendritic cells play a role for effective innate immune responses during Chlamydia pneumoniae infection in mice. PLoS One. 2012;7(10):e48655.

80 Deal, EM, Lahl, K, Narváez, CF, Butcher, EC, Greenberg, HB. Plasmacytoid dendritic cells promote rotavirus-induced human and murine $B$ cell responses. $J$ Clin Invest. 2013;123(6):2464-2474.

81 Dickinson, RE, Griffin, H, Bigley, V, Reynard, LN, Hussain, R, Haniffa, M, Lakey, JH, Rahman, T, Wang, XN, McGovern, N, Pagan, S, Cookson, S, McDonald, D, Chua, I, Wallis, J, Cant, A, Wright, M, Keavney, B, Chinnery, PF, Loughlin, J, Hambleton, S, Santibanez-Koref, M, Collin, M. Exome sequencing identifies GATA-2 mutation as the cause of dendritic cell, monocyte, B and NK lymphoid deficiency. Blood. 2011;118(10):2656-2658.

82 Bigley, V, Haniffa, M, Doulatov, S, Wang, XN, Dickinson, R, McGovern, N, Jardine, L, Pagan, S, Dimmick, I, Chua, I, Wallis, J, Lordan, J, Morgan, C, Kumararatne, DS, Doffinger, R, van der Burg, M, van Dongen, J, Cant, A, Dick, JE, Hambleton, S, Collin, M. The human syndrome of dendritic cell, monocyte, B and NK lymphoid deficiency. J Exp Med. 2011;208(2):227-234.

83 Hambleton, S, Salem, S, Bustamante, J, Bigley, V, Boisson-Dupuis, S, Azevedo, J, Fortin, A, Haniffa, M, Ceron-Gutierrez, L, Bacon, CM, Menon, G, Trouillet, C, McDonald, D, Carey, P, Ginhoux, F, Alsina, L, Zumwalt, TJ, Kong, XF, Kumararatne, D, Butler, K, Hubeau, M, Feinberg, J, Al-Muhsen, S, Cant, A, Abel, L, Chaussabel, D, Doffinger, R, Talesnik, E, Grumach, A, Duarte, A, Abarca, K, Moraes-Vasconcelos, D, Burk, D, Berghuis, A, Geissmann, F, Collin, M, Casanova, JL, Gros, P. IRF8 Mutations and Human Dendritic-Cell Immunodeficiency. N Engl J Med. 2011

84 Bigley, V, Maisuria, S, Cytlak, U, Jardine, L, Care, MA, Green, K, Gunawan, M, 
Milne, P, Dickinson, R, Wiscombe, S, Parry, D, Doffinger, R, Laurence, A, Lic, CF, Stoevesandt, O, Gennery, A, Cant, A, Tooze, R, Simpson, AJ, Hambleton, S, Savic, S, Doody, G, Collin, M. Bi-allelic IRF8 mutation: a complex immunodeficiency syndrome with dendritic cell deficiency, monocytopenia and immune dysregulation. J Allergy Clin Immunol. 2017

85 Dorfman, DM, Wilson, DB, Bruns, GA, Orkin, SH. Human transcription factor GATA-2. Evidence for regulation of preproendothelin-1 gene expression in endothelial cells. J Biol Chem. 1992;267(2):1279-1285.

86 Nardelli, J, Thiesson, D, Fujiwara, Y, Tsai, FY, Orkin, SH. Expression and genetic interaction of transcription factors GATA-2 and GATA-3 during development of the mouse central nervous system. Dev Biol. 1999;210(2):305-321.

87 Wlodarski, MW, Collin, M, Horwitz, MS. GATA2 deficiency and related myeloid neoplasms. Seminars in Hematology. 2017

88 Gröschel, S, Sanders, MA, Hoogenboezem, R, de Wit, E, Bouwman, BAM, Erpelinck, C, van der Velden, VHJ, Havermans, M, Avellino, R, van Lom, K, Rombouts, EJ, van Duin, M, Döhner, K, Beverloo, HB, Bradner, JE, Döhner, H, Löwenberg, B, Valk, PJM, Bindels, EMJ, de Laat, W, Delwel, R. A single oncogenic enhancer rearrangement causes concomitant EVI1 and GATA2 deregulation in leukemia. Cell. 2014;157(2):369-381.

89 Tamura, T, Kurotaki, D, Koizumi, S. Regulation of myelopoiesis by the transcription factor IRF8. Int J Hematol. 2015;101(4):342-351.

90 Lee, W, Kim, HS, Baek, SY, Lee, GR. Transcription factor IRF8 controls Th1-like regulatory T-cell function. Cell Mol Immunol. 2015

91 Shukla, V, Lu, R. IRF4 and IRF8: Governing the virtues of B Lymphocytes. Front Biol (Beijing). 2014;9(4):269-282.

92 Recaldin, T, Fear, DJ. Transcription factors regulating B cell fate in the germinal centre. Clin Exp Immunol. 2016;183(1):65-75.

93 Kierdorf, K, Erny, D, Goldmann, T, Sander, V, Schulz, C, Perdiguero, EG, Wieghofer, P, Heinrich, A, Riemke, P, Hölscher, C, Müller, DN, Luckow, B, Brocker, T, Debowski, K, Fritz, G, Opdenakker, G, Diefenbach, A, Biber, K, Heikenwalder, M, Geissmann, F, Rosenbauer, F, Prinz, M. Microglia emerge from erythromyeloid precursors via Pu.1- and Irf8-dependent pathways. Nat Neurosci. 2013;16(3):273-280.

94 Masuda, T, Tsuda, M, Yoshinaga, R, Tozaki-Saitoh, H, Ozato, K, Tamura, T, Inoue, K. IRF8 is a critical transcription factor for transforming microglia into a reactive phenotype. Cell Rep. 2012;1(4):334-340.

95 Masuda, T, Nishimoto, N, Tomiyama, D, Matsuda, T, Tozaki-Saitoh, H, Tamura, T, Kohsaka, S, Tsuda, M, Inoue, K. IRF8 is a transcriptional determinant for microglial motility. Purinergic Signal. 2014;10(3):515-521.

96 Hambleton, S, Salem, S, Bustamante, J, Bigley, V, Boisson-Dupuis, S, Azevedo, J, Fortin, A, Haniffa, M, Ceron-Gutierrez, L, Bacon, CM, Menon, G, Trouillet, C, McDonald, D, Carey, P, Ginhoux, F, Alsina, L, Zumwalt, TJ, Kong, XF, Kumararatne, D, Butler, K, Hubeau, M, Feinberg, J, Al-Muhsen, S, Cant, A, Abel, L, Chaussabel, D, Doffinger, R, Talesnik, E, Grumach, A, Duarte, A, Abarca, K, Moraes-Vasconcelos, D, Burk, D, Berghuis, A, Geissmann, F, Collin, M, Casanova, JL, Gros, P. IRF8 mutations and human dendritic-cell immunodeficiency. N Engl J Med. 2011;365(2):127-138.

97 Mace, EM, Bigley, V, Gunesch, JT, Chinn, IK, Angelo, LS, Care, MA, Maisuria, S, Keller, MD, Togi, S, Watkin, LB, LaRosa, DF, Jhangiani, SN, Muzny, DM, StrayPedersen, A, Coban Akdemir, Z, Smith, JB, Hernández-Sanabria, M, Le, DT, Hogg, GD, Cao, TN, Freud, AG, Szymanski, EP, Savic, S, Collin, M, Cant, AJ, Gibbs, RA, Holland, SM, Caligiuri, MA, Ozato, K, Paust, S, Doody, GM, Lupski, JR, Orange, JS. Biallelic mutations in IRF8 impair human NK cell maturation and 
function. J Clin Invest. 2017;127(1):306-320.

98 Allman, D, Dalod, M, Asselin-Paturel, C, Delale, T, Robbins, SH, Trinchieri, G, Biron, CA, Kastner, $\mathrm{P}$, Chan, $\mathrm{S}$. Ikaros is required for plasmacytoid dendritic cell differentiation. Blood. 2006;108(13):4025-4034.

99 Kuehn, HS, Boisson, B, Cunningham-Rundles, C, Reichenbach, J, StrayPedersen, A, Gelfand, EW, Maffucci, P, Pierce, KR, Abbott, JK, Voelkerding, KV, South, ST, Augustine, NH, Bush, JS, Dolen, WK, Wray, BB, Itan, Y, Cobat, A, Sorte, HS, Ganesan, S, Prader, S, Martins, TB, Lawrence, MG, Orange, JS, Calvo, KR, Niemela, JE, Casanova, JL, Fleisher, TA, Hill, HR, Kumanovics, A, Conley, ME, Rosenzweig, SD. Loss of B Cells in Patients with Heterozygous Mutations in IKAROS. N Engl J Med. 2016;374(11):1032-1043.

100 Hoshino, A, Okada, S, Yoshida, K, Nishida, N, Okuno, Y, Ueno, H, Yamashita, M, Okano, T, Tsumura, M, Nishimura, S, Sakata, S, Kobayashi, M, Nakamura, H, Kamizono, J, Mitsui-Sekinaka, K, Ichimura, T, Ohga, S, Nakazawa, Y, Takagi, M, Imai, K, Shiraishi, Y, Chiba, K, Tanaka, H, Miyano, S, Ogawa, S, Kojima, S, Nonoyama, S, Morio, T, Kanegane, H. Abnormal hematopoiesis and autoimmunity in human subjects with germline IKZF1 mutations. J Allergy Clin Immunol. 2016

101 Cytlak, U, Resteu, A, Bogaert, DJ, Kuehn, HS, Altmann, T, Gennery, A, Jackson, G, Kumanovics, A, Voelkerding, KV, Prader, S, Dullaers, M, Reichenbach, J, Hill, HR, Haerynck, F, Rosenzweig, SD, Collin, M, Bigley, V. Dendritic cell and monocytes anomalies in human IKZF1 deficiency. Nat Comms in review. 2017

$102 \mathrm{Hu}, \mathrm{Y}$, Yoshida, T, Georgopoulos, K. Transcriptional circuits in B cell transformation. Curr Opin Hematol. 2017;24(4):345-352.

103 Rouillard, AD, Gundersen, GW, Fernandez, NF, Wang, Z, Monteiro, CD, McDermott, MG, Ma'ayan, A. The harmonizome: a collection of processed datasets gathered to serve and mine knowledge about genes and proteins. Database (Oxford). 2016;2016

104 Lagresle-Peyrou, C, Six, EM, Picard, C, Rieux-Laucat, F, Michel, V, Ditadi, A, Demerens-de Chappedelaine, C, Morillon, E, Valensi, F, Simon-Stoos, KL, Mullikin, JC, Noroski, LM, Besse, C, Wulffraat, NM, Ferster, A, Abecasis, MM, Calvo, F, Petit, C, Candotti, F, Abel, L, Fischer, A, Cavazzana-Calvo, M. Human adenylate kinase 2 deficiency causes a profound hematopoietic defect associated with sensorineural deafness. Nat Genet. 2009;41(1):106-111.

105 Pannicke, U, Honig, M, Hess, I, Friesen, C, Holzmann, K, Rump, EM, Barth, TF, Rojewski, MT, Schulz, A, Boehm, T, Friedrich, W, Schwarz, K. Reticular dysgenesis (aleukocytosis) is caused by mutations in the gene encoding mitochondrial adenylate kinase 2. Nat Genet. 2009;41(1):101-105.

106 Siedlar, M, Rudzki, Z, Strach, M, Trzyna, E, Pituch-Noworolska, A, BlautSzlosarczyk, A, Bukowska-Strakova, K, Lenart, M, Grodzicki, T, Zembala, M. Familial occurrence of warts, hypogammaglobulinemia, infections, and myelokathexis (WHIM) syndrome. Arch Immunol Ther Exp (Warsz). 2008;56(6):419-425.

107 Reith, W, Mach, B. The bare lymphocyte syndrome and the regulation of MHC expression. Annu Rev Immunol. 2001;19:331-373.

108 Hanna, S, Etzioni, A. MHC class I and II deficiencies. J Allergy Clin Immunol. 2014;134(2):269-275.

109 Malinova, D, Fritzsche, M, Nowosad, CR, Armer, H, Munro, PM, Blundell, MP, Charras, G, Tolar, P, Bouma, G, Thrasher, AJ. WASp-dependent actin cytoskeleton stability at the dendritic cell immunological synapse is required for extensive, functional T cell contacts. J Leukoc Biol. 2016;99(5):699-710.

110 Baptista, MA, Keszei, M, Oliveira, M, Sunahara, KK, Andersson, J, Dahlberg, Cl, Worth, AJ, Lieden, A, Kuo, IC, Wallin, RP, Snapper, SB, Eidsmo, L, Scheynius, 
A, Karlsson, MC, Bouma, G, Burns, SO, Forsell, MN, Thrasher, AJ, Nylen, S, Westerberg, LS. Deletion of Wiskott-Aldrich syndrome protein triggers Rac2 activity and increased cross-presentation by dendritic cells. Nat Commun. 2016;7:12175.

$111 \mathrm{Ma}, \mathrm{DY}$, Clark, EA. The role of CD40 and CD154/CD40L in dendritic cells. Semin Immunol. 2009;21(5):265-272.

112 Davies, EG, Thrasher, AJ. Update on the hyper immunoglobulin M syndromes. $\mathrm{Br}$ J Haematol. 2010;149(2):167-180.

113 Reizis, B. Regulation of plasmacytoid dendritic cell development. Curr Opin Immunol. 2010;22(2):206-211.

114 de Winter, CF, Baas, M, Bijlsma, EK, van Heukelingen, J, Routledge, S, Hennekam, RC. Phenotype and natural history in 101 individuals with PittHopkins syndrome through an internet questionnaire system. Orphanet $J$ Rare Dis. 2016;11:37.

115 Kerkmann, M, Rothenfusser, S, Hornung, V, Towarowski, A, Wagner, M, Sarris, A, Giese, T, Endres, S, Hartmann, G. Activation with CpG-A and CpG-B oligonucleotides reveals two distinct regulatory pathways of type I IFN synthesis in human plasmacytoid dendritic cells. J Immunol. 2003;170(9):4465-4474.

116 Ciancanelli, MJ, Huang, SX, Luthra, P, Garner, H, Itan, Y, Volpi, S, Lafaille, FG, Trouillet, C, Schmolke, M, Albrecht, RA, Israelsson, E, Lim, HK, Casadio, M, Hermesh, T, Lorenzo, L, Leung, LW, Pedergnana, V, Boisson, B, Okada, S, Picard, C, Ringuier, B, Troussier, F, Chaussabel, D, Abel, L, Pellier, I, Notarangelo, LD, Garcia-Sastre, A, Basler, CF, Geissmann, F, Zhang, SY, Snoeck, HW, Casanova, JL. Infectious disease. Life-threatening influenza and impaired interferon amplification in human IRF7 deficiency. Science. 2015;348(6233):448-453.

117 Li, HS, Yang, CY, Nallaparaju, KC, Zhang, H, Liu, YJ, Goldrath, AW, Watowich, SS. The signal transducers STAT5 and STAT3 control expression of Id2 and E22 during dendritic cell development. Blood. 2012;120(22):4363-4373.

118 Saito, M, Nagasawa, M, Takada, H, Hara, T, Tsuchiya, S, Agematsu, K, Yamada, M, Kawamura, N, Ariga, T, Tsuge, I, Nonoyama, S, Karasuyama, H, Minegishi, Y. Defective IL-10 signaling in hyper-IgE syndrome results in impaired generation of tolerogenic dendritic cells and induced regulatory $T$ cells. $J$ Exp Med. 2011;208(2):235-249.

119 Haapaniemi, EM, Kaustio, M, Rajala, HL, van Adrichem, AJ, Kainulainen, L, Glumoff, V, Doffinger, R, Kuusanmäki, H, Heiskanen-Kosma, T, Trotta, L, Chiang, S, Kulmala, P, Eldfors, S, Katainen, R, Siitonen, S, Karjalainen-Lindsberg, ML, Kovanen, PE, Otonkoski, T, Porkka, K, Heiskanen, K, Hänninen, A, Bryceson, YT, Uusitalo-Seppälä, R, Saarela, J, Seppänen, M, Mustjoki, S, Kere, J. Autoimmunity, hypogammaglobulinemia, lymphoproliferation, and mycobacterial disease in patients with activating mutations in STAT3. Blood. 2015;125(4):639_ 648.

120 Park, SJ, Nakagawa, T, Kitamura, H, Atsumi, T, Kamon, H, Sawa, S, Kamimura, D, Ueda, N, Iwakura, Y, Ishihara, K, Murakami, M, Hirano, T. IL-6 regulates in vivo dendritic cell differentiation through STAT3 activation. $J$ Immunol. 2004;173(6):3844-3854.

121 Corinti, S, Albanesi, C, la Sala, A, Pastore, S, Girolomoni, G. Regulatory activity of autocrine IL-10 on dendritic cell functions. J Immunol. 2001;166(7):4312-4318.

122 Fukao, T, Matsuda, S, Koyasu, S. Synergistic effects of IL-4 and IL-18 on IL-12dependent IFN-gamma production by dendritic cells. J Immunol. 2000;164(1):6471.

123 Puccetti, P, Belladonna, ML, Grohmann, U. Effects of IL-12 and IL-23 on antigenpresenting cells at the interface between innate and adaptive immunity. Crit Rev 
Immunol. 2002;22(5-6):373-390.

124 Mascanfroni, ID, Yeste, A, Vieira, SM, Burns, EJ, Patel, B, Sloma, I, Wu, Y, Mayo, L, Ben-Hamo, R, Efroni, S, Kuchroo, VK, Robson, SC, Quintana, FJ. IL-27 acts on DCs to suppress the $T$ cell response and autoimmunity by inducing expression of the immunoregulatory molecule CD39. Nat Immunol. 2013;14(10):1054-1063.

125 Melillo, JA, Song, L, Bhagat, G, Blazquez, AB, Plumlee, CR, Lee, C, Berin, C, Reizis, B, Schindler, C. Dendritic cell (DC)-specific targeting reveals Stat3 as a negative regulator of DC function. $J$ Immunol. 2010;184(5):2638-2645.

126 Keles, S, Jabara, HH, Reisli, I, McDonald, DR, Barlan, I, Hanna-Wakim, R, Dbaibo, G, Lefranc, G, Al-Herz, W, Geha, RS, Chatila, TA. Plasmacytoid dendritic cell depletion in DOCK8 deficiency: rescue of severe herpetic infections with IFNa 2b therapy. J Allergy Clin Immunol. 2014;133(6):1753-5.e3.

127 Eisenbarth, SC, Williams, A, Colegio, OR, Meng, H, Strowig, T, Rongvaux, A, Henao-Mejia, J, Thaiss, CA, Joly, S, Gonzalez, DG, Xu, L, Zenewicz, LA, Haberman, AM, Elinav, E, Kleinstein, SH, Sutterwala, FS, Flavell, RA. NLRP10 is a NOD-like receptor essential to initiate adaptive immunity by dendritic cells. Nature. 2012;484(7395):510-513.

128 Harada, Y, Tanaka, Y, Terasawa, M, Pieczyk, M, Habiro, K, Katakai, T, HanawaSuetsugu, K, Kukimoto-Niino, M, Nishizaki, T, Shirouzu, M, Duan, X, Uruno, T, Nishikimi, A, Sanematsu, F, Yokoyama, S, Stein, JV, Kinashi, T, Fukui, Y. DOCK8 is a Cdc42 activator critical for interstitial dendritic cell migration during immune responses. Blood. 2012;119(19):4451-4461.

129 Krishnaswamy, JK, Singh, A, Gowthaman, U, Wu, R, Gorrepati, P, Sales Nascimento, M, Gallman, A, Liu, D, Rhebergen, AM, Calabro, S, Xu, L, Ranney, P, Srivastava, A, Ranson, M, Gorham, JD, McCaw, Z, Kleeberger, SR, Heinz, LX, Müller, AC, Bennett, KL, Superti-Furga, G, Henao-Mejia, J, Sutterwala, FS, Williams, A, Flavell, RA, Eisenbarth, SC. Coincidental loss of DOCK8 function in NLRP10-deficient and $\mathrm{C} 3 \mathrm{H} / \mathrm{HeJ}$ mice results in defective dendritic cell migration. Proc Natl Acad Sci U S A. 2015;112(10):3056-3061.

130 Fontana, S, Parolini, S, Vermi, W, Booth, S, Gallo, F, Donini, M, Benassi, M, Gentili, F, Ferrari, D, Notarangelo, LD, Cavadini, P, Marcenaro, E, Dusi, S, Cassatella, M, Facchetti, F, Griffiths, GM, Moretta, A, Notarangelo, LD, Badolato, R. Innate immunity defects in Hermansky-Pudlak type 2 syndrome. Blood. 2006;107(12):4857-4864.

131 Sugita, M, Cao, X, Watts, GF, Rogers, RA, Bonifacino, JS, Brenner, MB. Failure of trafficking and antigen presentation by CD1 in AP-3-deficient cells. Immunity. 2002;16(5):697-706.

132 Blasius, AL, Arnold, CN, Georgel, P, Rutschmann, S, Xia, Y, Lin, P, Ross, C, Li, X, Smart, NG, Beutler, B. Slc15a4, AP-3, and Hermansky-Pudlak syndrome proteins are required for Toll-like receptor signaling in plasmacytoid dendritic cells. Proc Natl Acad Sci U S A. 2010;107(46):19973-19978.

133 Prandini, A, Salvi, V, Colombo, F, Moratto, D, Lorenzi, L, Vermi, W, De Francesco, MA, Notarangelo, LD, Porta, F, Plebani, A, Facchetti, F, Sozzani, S, Badolato, R. Impairment of dendritic cell functions in patients with adaptor protein-3 complex deficiency. Blood. 2016;127(26):3382-3386.

134 Boztug, K, Klein, C. Genetic etiologies of severe congenital neutropenia. Curr Opin Pediatr. 2011;23(1):21-26.

135 Horwitz, MS, Corey, SJ, Grimes, HL, Tidwell, T. ELANE mutations in cyclic and severe congenital neutropenia: genetics and pathophysiology. Hematol Oncol Clin North Am. 2013;27(1):19-41, vii.

136 Hemont, C, Neel, A, Heslan, M, Braudeau, C, Josien, R. Human blood mDC subsets exhibit distinct TLR repertoire and responsiveness. J Leukoc Biol. 
2013;93(4):599-609.

137 Hacker, $\mathrm{H}$, Tseng, $\mathrm{PH}$, Karin, M. Expanding TRAF function: TRAF3 as a tri-faced immune regulator. Nat Rev Immunol. 2011;11(7):457-468.

138 Casanova, V, Naval-Macabuhay, I, Massanella, M, Rodriguez-Garcia, M, Blanco, J, Gatell, JM, Garcia, F, Gallart, T, Lluis, C, Mallol, J, Franco, R, Climent, N, McCormick, PJ. Adenosine deaminase enhances the immunogenicity of human dendritic cells from healthy and HIV-infected individuals. PLoS One. 2012;7(12):e51287.

139 Rivas-Caicedo, A, Soldevila, G, Fortoul, TI, Castell-Rodriguez, A, Flores-Romo, $\mathrm{L}$, Garcia-Zepeda, EA. Jak3 is involved in dendritic cell maturation and CCR7dependent migration. PLoS One. 2009;4(9):e7066.

140 Goldstein, DB, Allen, A, Keebler, J, Margulies, EH, Petrou, S, Petrovski, S, Sunyaev, S. Sequencing studies in human genetics: design and interpretation. Nat Rev Genet. 2013;14(7):460-470.

141 Itan, Y, Casanova, JL. Novel primary immunodeficiency candidate genes predicted by the human gene connectome. Front Immunol. 2015;6:142. 